\title{
GROUND-WATER RESOURCES IN LAJAS VALLEY, PUERTO RICO
}

\author{
By Robert P. Graves
}

U.S. GEOLOGICAL SURVEY

Water-Resources Investigations Report 89-4182

Prepared in cooperation with the

DEPARTMENT OF AGRICULTURE OF PUERTO RICO

AND THE PUERTO RICO INDUSTRIAL DEVELOPMENT COMPANY

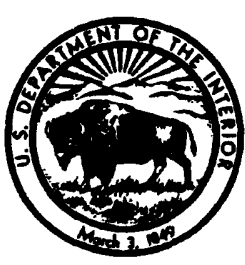

San Juan, Puerto Rico

1991 


\section{U.S. DEPARTMENT OF THE INTERIOR MANUEL LUJAN, JR, Secretary \\ U.S. GEOLOGICAL SURVEY \\ Dallas L. Peck, Director}

For additional information write to:

District Chief

U.S. Geological Survey

P.O. Box 364424

San Juan, Puerto Rico 00936-4424



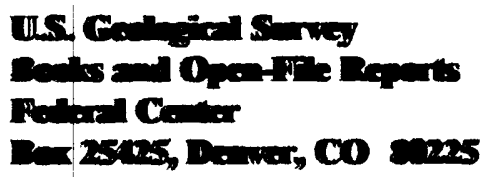




\section{CONIENTS}

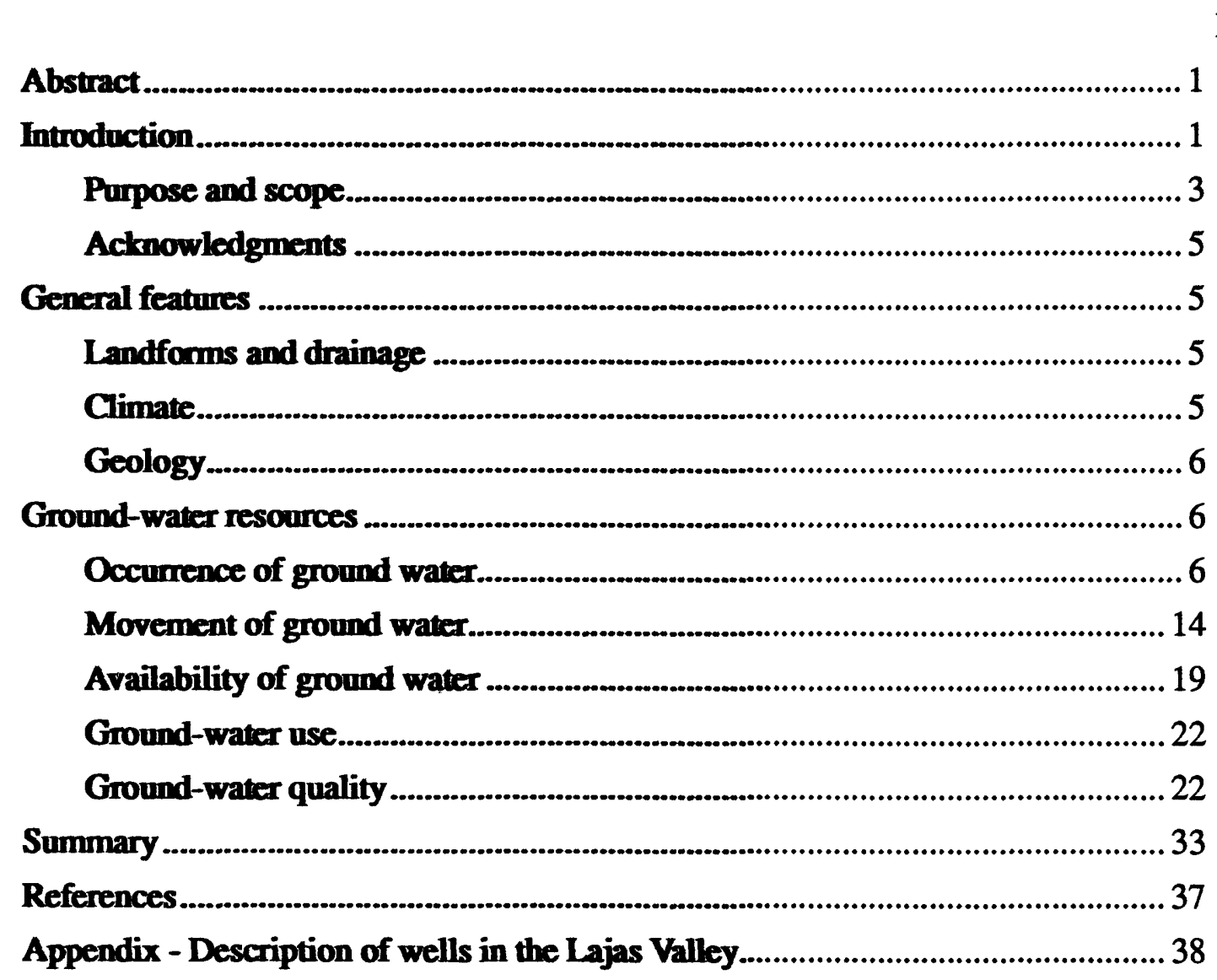




\section{ILLUSTRATIONS}

Page

Figures

1. Map showing location of the Lajas Valley and important

hydrologic features. 2

2. Map showing location of inventoried wells and well batteries in the Lajas Valley 4

3. Bar graph showing mean monthly rainfall for Lajas Substation, 1966 - 1986 7

4. Map showing generalized geology of the Lajas Valley 8

5. Diagram showing stratigraphic section for well 161, upper part (A) and lower part (B)

6. Diagram showing stratigraphic section for well 162, upper part (A) and lower part (B).

7. Diagram showing generalized hydrogeologic section of the Lajas

Valley

8. Graph showing mean annual water levels at well batteries A, B, and C, Lajas Valley, 1986.

9. Hydrograph showing water-level altitude in wells 147 and 149

at well battery A, and bar graph of monthly rainfall at

Lajas Substation, August 1984 through November 1986.

10. Diagram showing lithology and geophysical logs for well 146 and

chloride concentration in selected wells at well battery $A$ 18

11. Map showing potentiometric surface of the Lajas Valley alluvial aquifer, March 1986.

12. Hydrograph showing weekly water levels in well 105, December 1981 through May 1986

13. Graph showing chloride concentration with depth for wells 161 and 162, March 1987 28

14. Graph showing mean annual chloride concentration with depth at well batteries A, B, and C, Lajas Valley, 1986

15. Map showing chloride concentrations in water from wells screened at depths of 39 feet or less, in the Lajas Valley, March 1986 


\section{ILLUSTRATIONS--Continued}

Page

Figures

16. Map showing chloride concentrations in water from wells

screened at depths of 40 to 79 feet, in the Lajas Valley,

March 1986

17. Map showing chloride concentrations in water from wells

screened at depths greater than 79 , feet in the Lajas

Valley, March 1986

TABLES

Page

Tables

1. Depth to first water-bearing zone in test holes and static water level in cased wells ...

2. Transmissivity of the alluvial aquifer estimated from specific

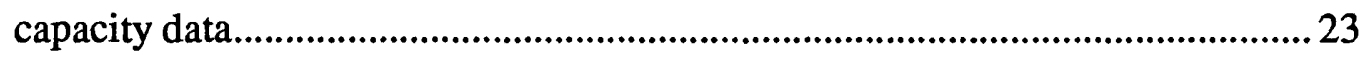

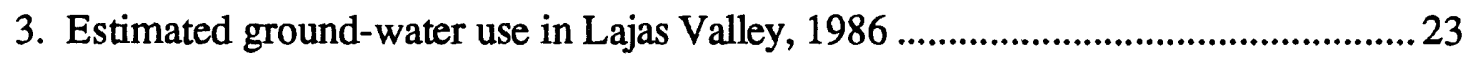

4. Chemical analyses of ground water in Lajas Valley....................................................24

5. Concentrations of iron, manganese, dissolved solids, and chloride exceeding U.S. Environmental Protection Agency drinking water standards in ground water from wells in Lajas Valley

6. Specific conductance and chloride concentrations in ground water at selected wells in Lajas Valley, March 1986 


\section{CONVERSION FACTORS}

For the convenience of readers who prefer to use Metric Units, the following conversion factors may be used:

Multiply inch-pound units

inch (in.)

foot $(\mathrm{ft})$

mile (mi)

acre

square foot $\left(\mathrm{ft}^{2}\right)$

square mile $\left(\mathrm{mi}^{2}\right)$

acre-foot (acre-ft)

cubic foot per second $\left(\mathrm{ft}^{3} / \mathrm{s}\right)$

gallon per minute (gal/min)

million gallons per day (Mgal/d)

degrees Fahrenheit $\left({ }^{\circ} \mathrm{F}\right)$

gallon per minute per foot

[(gal/min)/ft]

square foot per day $\left(\mathrm{ft}^{2} / \mathrm{d}\right)$ by

Length

25.4

0.3048

1.609

Area

4,047

0.09294

2.590

Volume

1,233

Elow

0.02832

0.06308

0.04381

Temperature

${ }^{\circ} \mathrm{C}=5 / 9 \times\left({ }^{\circ} \mathrm{F}-32\right)$

Specific capacity

0.2070

liter per second per meter [(L/s)/m]

Transmissivity

0.09290
To obtain metric units

millimeter (mm)

meter (m)

kilometer (km)

square meter $\left(\mathrm{m}^{2}\right)$

square meter $\left(\mathrm{m}^{2}\right)$

square kilometer $\left(\mathrm{km}^{2}\right)$

cubic meter $\left(\mathrm{m}^{3}\right)$

cubic meter per second $\left(\mathrm{m}^{3} / \mathrm{s}\right)$

cubic meter per day $\left(\mathrm{m}^{3} / \mathrm{d}\right)$

degrees Celsius ( ${ }^{\circ} \mathrm{C}$ ) liter per second $(\mathrm{L} / \mathrm{s})$ square meter per day $\left(\mathrm{m}^{2} / \mathrm{d}\right)$ 


\title{
GROUND-WATER RESOURCES IN LAJAS VALLEY, PUERTO RICO
}

\author{
by RobertP. Graves
}

\begin{abstract}
The principal aquifer in the Lajas Valley is a nonhomogeneous, anisotropic confined aquifer consisting of alluvial deposits of Quaternary age. The altitude of the potentiometric surface of the Lajas Valley alluvial aquifer ranges from more than 50 feet above mean sea level near its northern and southern boundary to about 12 feet above mean sea level in the central part of the valley. Values of aquifer transmissivity range from 670 to 8,020 square feet per day; the storage coefficient of the aquifer is approximately 0.00093 . Yields in the alluvial aquifer commonly range from 5 to 300 gallons per minute. Water-quality analyses of ground water in the alluvial aquifer indicated that, at several sites, the US. Environmental Protection Agency drinking water standards for iron, manganese, chloride and dissolved solids were exceeded. Elevated chloride concentrations in excess of 5,000 milligrams per liter were measured in water samples from several wells.

Consolidated clastic and carbonate strata of Cretaceous and Tertiary age underlie the alluvial aquifer. Well yields for two test holes drilled into this rock were about 200 gallons per minute. Chloride concentrations in ground water in this strata ranged from 100 to 2,100 milligrams per liver.
\end{abstract}

\section{INTRODUCTION}

The Lajas Valley in southwestern Puerto Rico (fig. 1) is a large (about 32,500 acres), flat lowland, which is being considered for agricultural and industrial development by the Department of Agriculture of Puerto Rico (DAPR) and the Puerto Rico Industrial Development Company (PRIDCO). Historically, ground water in the Lajas Valley has been under-utilized because of its elevated chloride concentration. Fresh ground water is known to occur in the recharge areas; but bractish water is reported to be present throughout much of the alluvial aquifer that underlies the valley (Anderson, 1977). Anderson further reported that the analyses of ground water collected from selocted test holes indicated that chloride concentration docreased with depth. The depth of these test holes was less than $\mathbf{2 0 0}$ feet. It was suspected that fresh ground water occurred in Cretaceous and Tertiary limestone deposits, which were believed to underlie alluvial deposits of Quetemary age in the Lajes Valley.

The principal source of freshwater in the valley is an aqueduct from Lago Loco, which supplies appouimately 4,600 acro-ft/mo (acre-feet per month) of water to the valley (fig. 1). Planned development of a rice industry by DAPR and new industrial development by PRIDCO 


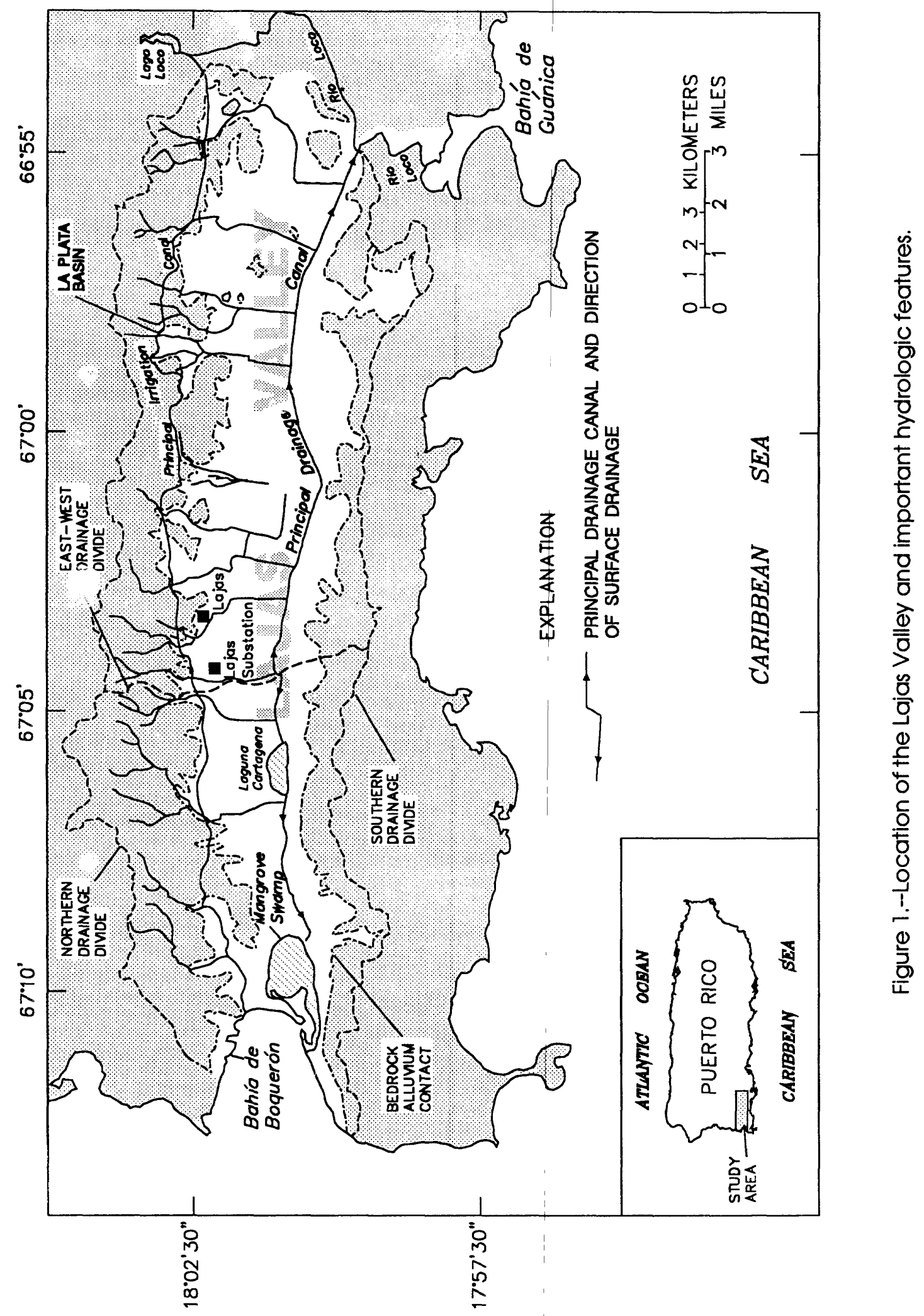


will require approximately 6,000 and 3,200 acre-ft/mo of water, respectively. Because the surface-water resources in the Lajas Valley are not adequate to meet the projected water demand, fresh ground-water supplies are needed to supplement the surface-water supply.

\section{Purpose and Scope}

This report summarizes the results of a three-year cooperative investigation initiated in 1983 between the U.S. Geological Survey, DAPR, and PRIDCO. The objectives of this study are to:

1. Assess the ground-water resources of the alluvial deposits in the Lajas Valley in terms of its occurrence, availability, and chemistry.

2. Determine if fresh ground water occurs in the limestone deposits underlying the Lajas Valley.

The objectives of the investigation were addressed by first evaluating results of all previous hydrologic studies of the area. After the available data were compiled, a data-collection program was initiated in 1984 to provide additional hydrologic information. This program included an inventory of information on well specifications, water levels, well yield, drawdown, and water quality. To determine the occurrence of ground water in the alluvial deposits, batteries of test wells were installed at three sites to depths ranging from 1 to 247 feet below land surface. Additional wells were drilled to help define the potentiometric surface of the alluvial aquifer. To provide a better understanding of the geohydrologic character of the alluvial aquifer and the hydrologic relation between the alluvial aquifer and the suspected underlying limestone deposits, two test wells were drilled to depths of 636 and 856 feet. These test wells were drilled using the dual tube method; a technique that permits the collection of continuous geologic cores, hydrologic data (aquifer yield, head change, and change in aquifer characteristics), and water-quality data as the well is drilled.

A continuous recorder was used to monitor ground-water level fluctuations in the alluvial aquifer in the central portion of the valley. An aquifer test was conducted to determine the transmissivity and storage properties of the alluvial aquifer.

Water samples were collected periodically at the different well batteries to study the change in chloride concentration with depth. Additional water-quality samples from selected wells were collected and analyzed for major cations and anions and the trace elements of iron, manganese, barium, and aluminum.

The location of wells used in this investigation are shown in figure ' 2 . Information on these wells is given in the appendix of this report. The well numbers in figure 2 and in the appendix apply 


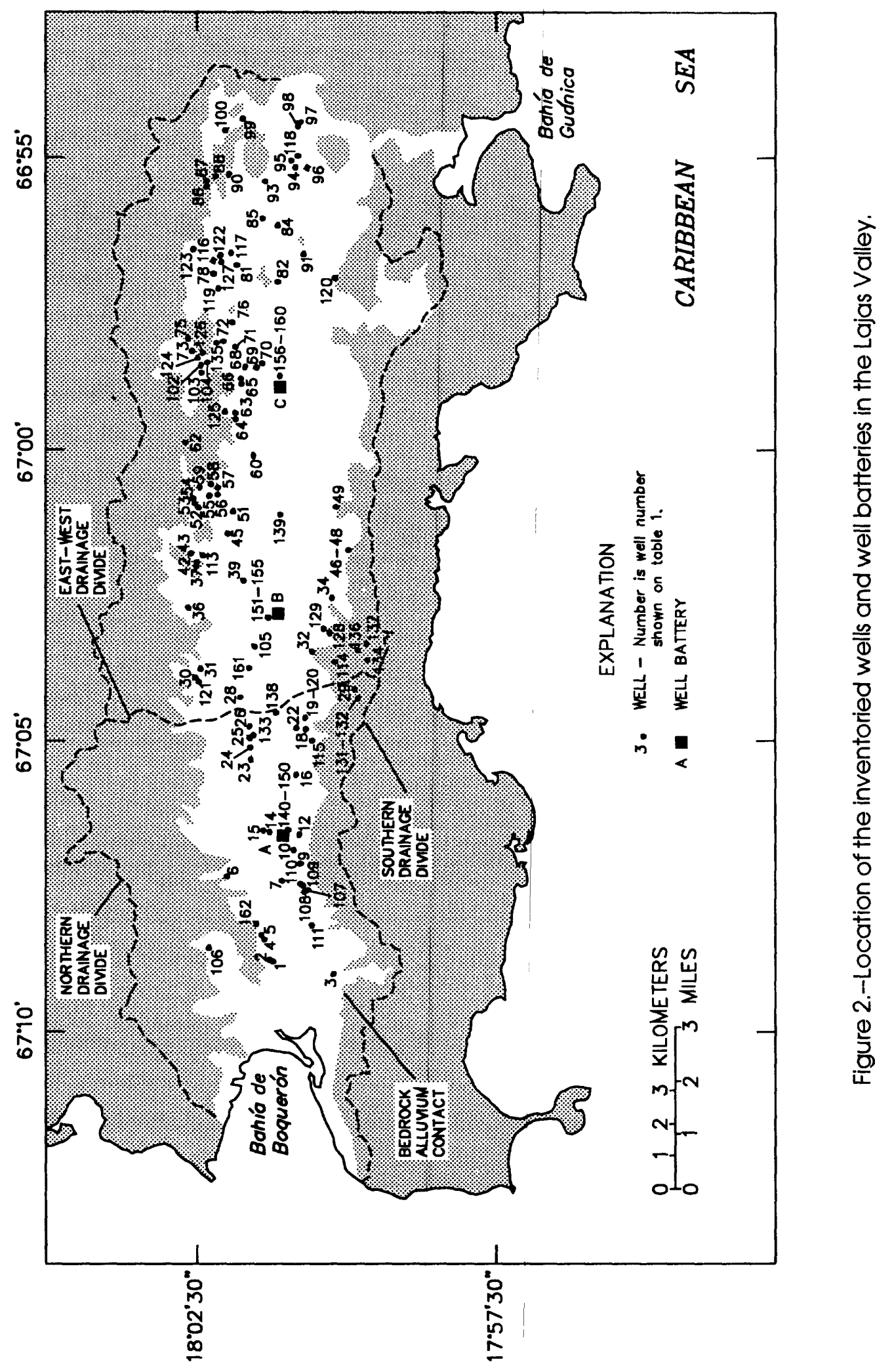


only to this report; however, site identification numbers presented in the appendix conform with the established U.S. Geological Survey Ground-Water Site Inventory well numbering scheme.

\section{Acknowledgments}

The author gratefully acknowledges the individuals who provided assistance and cooperation throughout the project. Special acknowledgment is extended to private landowners José B. Ramírez-Acosta, Miguel Carlo, Johnny González, Olmar C. López, and Rafael Salcedo-Rivera, and to the University of Puerto Rico Agricultural Experimental Station, Lajas, for allowing the installation of test wells on their property. Appreciation is also extended to Aquaculture Enterprises, Inc. for the hydrologic data they provided and for their assistance in conducting an aquifer test at their facility.

\section{GENERAL FEATURES}

\section{Landforms and Drainage}

The Lajas Valley is located in the extreme southwestern corner of Puerto Rico (fig. 1). The valley, which is oriented along an east-west axis, is 18 miles long and ranges from 1 to 3 miles wide. The valley is open at both ends, draining into Río Loco and Bahía de Guánica to the east, and Bahía de Boquerón to the west. Foothills on the north and south sides of the valley rise to a maximum altitude of 980 and 820 feet above mean sea level, respectively. The altitude of the central valley floor varies from sea level near Bahía de Boquerón to approximately 43 feet above mean sea level along the east-west drainage divide that is located 6.5 miles east of Bahía de Boquerón. North and south of the central valley floor, the land surface rises to altitudes of as much as 164 feet above mean sea level at the base of the bordering foothills. Natural streams that flow out of the foothills into the Lajas Valley are small and ephemeral (fig. 1). Following heavy rains, flow from these streams disappears in the alluvial deposits of the Lajas Valley (Anderson, 1977).

Man-induced surface-water flow and drainage also is evident in the Lajas Valley. A 23 mile long gravity-fed irrigation canal extends westward from Lago Loco to Bahía de Boquerón along the base of the northern foothills (fig. 1). A series of drainage canals have been constructed within the valley. The main drainage canal runs east-west along the southern edge of the valley with direction of flow being controlled by the central inner valley drainage divide. Surface-water bodies within the Lajas Valley includes Laguna Cartagena and a mangrove swamp near Bahía de Boquerón (fig. 1). 


\section{Climate}

The climate in Lajas Valley is classified as moist to dry subhumid tropical (Jones and Pico, 1955). The mean annual air temperature recorded by the National Oceanic and Atmospheric Administration (NOAA) at the Lajas Substation is 77 degrees Fahrenheit (U.S. Department of Commerce, 1986) (fig. 1). Average annual rainfall at the Lajas Substation is 43 inches. Two seasons occur within the Lajas Valley, a dry season that extends from January to March, and a wet season from August through November (fig. 3). Average annual pan evaporation reported by NOAA between 1982 and 1986 for the Lajas Substation is 60 inches a year.

\section{Geology}

Metamorphic, igneous (plutonic and volcanic), and sedimentary rocks that crop out and underlie the study area range from Late Jurassic to Quaternary age (Volckmann, 1984a, b, c, and d) (fig. 4). For hydrogeologic purposes, igneous rock is considered to be the basement underlying the Lajas Valley.

Cores collected from test wells 161 and 162 indicate that igneous rock underlies the valley at a depth of 540 to 875 feet below land surface, respectively. Lithologic descriptions for these two deep wells are presented in figures 5 and 6 . Consolidated clastic and carbonate strata (referred to in this report as sedimentary rock) of Cretaceous and Tertiary age overlie the igneous rock. The sedimentary rock is about 850 feet thick in well 162 and about 364 feet thick in well 161 (fig. 7). This sedimentary rock is the limestone described by Anderson (1977). Unconsolidated alluvial deposits of Quaternary age, which are characterized by silt, clay, and lenses of sand, overlie the consolidated sedimentary rock. The thickness of the alluvial deposits exceeds 210 feet in the eastern end of the valley (fig. 7). Alluvial fan deposits of sand and gravel are found near the northern and southern edge of the valley and grade into the silt and clay deposits of the central valley (Volckmann, 1984a, b, and c).

\section{GROUND-WATER RESOURCES}

\section{Occurrence of Ground Water}

The principal aquifer discussed in this report is a nonhomogenous, anisotropic confined aquifer comprised of alluvial deposits of Quaternary age (fig. 7). The upper confining unit of the aquifer consists of clay deposits. Locally, at the base of the foothills in the alluvial fan deposits near the northern and southern edge of the valley, ground water can occur under water-table conditions (Anderson, 1977).

The alluvial deposits are in hydraulic connection with the underlying sedimentary rock of Cretaceous and Tertiary age, but, because of the difference in rock type, significant differences 




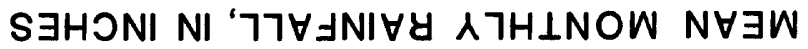




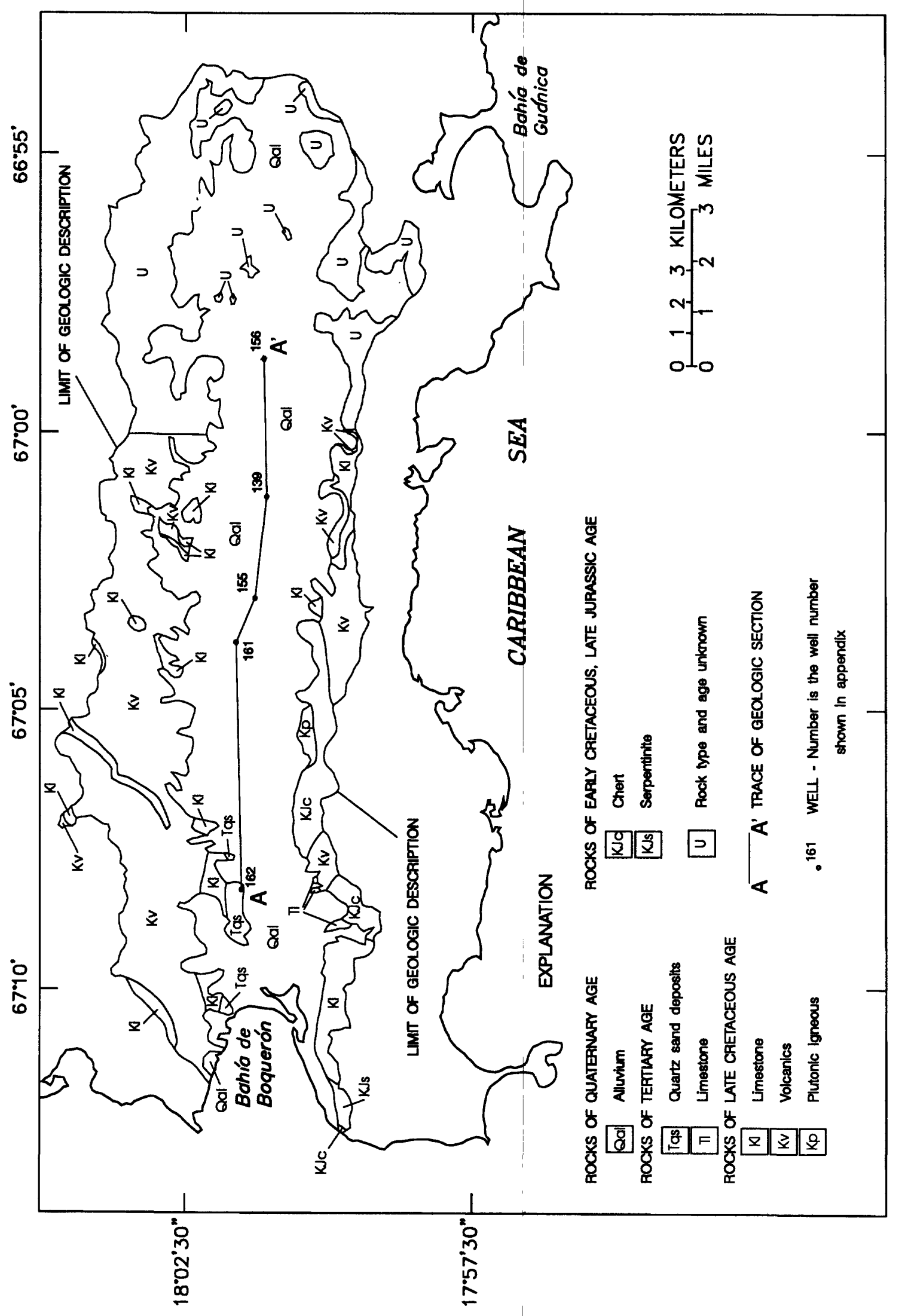




\section{Depth Lithology
(feet)}



Description of Units

\begin{abstract}
dark yellowish brown to moderate yellowish brown, unconsolidated, locally silty, with thin layers of loose coarse grain sand and minor angular volcanic gravel and pebbles
\end{abstract}

coarse grained, volcanic, unconsolidated, with volcanic gravel and pebbles

yellowish brown, unconsolidated, interlayered with coarse volcanic sand and gravel

unconsolidated with coarse grain sand

dark yellowish and reddish brown, unconsolidated, locally silty, with loose medium grain sand

yellowish brown, unconsolidated, medium to coarse grained, moderately sorted, very clayey

yellowish brown, unconsolidated, locally silty, with subrounded, medium grained, moderate to well sorted sand

pale yellowish orange to grayish orange, well indurated with sparry cement, predominantly highly fossilferous, proliferation of bioclasts and mollusks; locally clayey, fair to good moldic porosity and fine to medium grained calcarenite

pale yellowish orange, well indurated, predominantly fine grained to microspar cement, slightly to moderately clayey

medium yellowish orange, well indurated, coarse grained calcarenite, fine grained solution moldic porosity, locally rich in foraminifera, grading to calcareous sandstone with depth

Figure 5.--Stratigraphic section for well 161, upper part (A) and lower part (B). 


\section{Depth Lithology \\ (foet)}

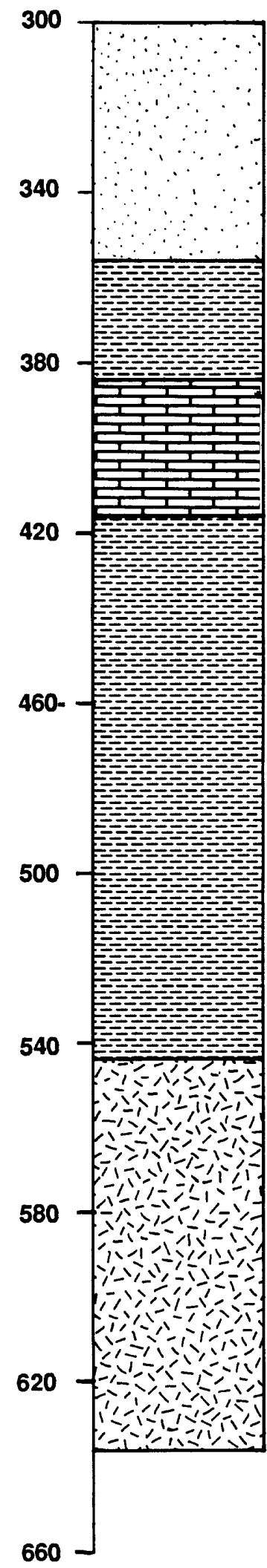

\section{Description of Units}

SANDSTONE

medium to coarse grained, moderately to well indurated, minor lenses of loose sand, locally fossiliferous

greenish gray, moderately to well indurated, with limestone angular clasts, calcareous, locally with coarse grained quartzose sandstone, minor silt, minor organic structure (lignite?)

dark gray, dusky brown, highly bioclastic, wackestone to packstone, locally with coral reef debris, locally with spar cement, locally fine to coarse grained porosity, grading to and interbedded with claystone

\section{CLAYSTTONE}

dark greenish gray, locally moderately indurated, with silty fine grained sand lenses, and dark gray biosparite, highly bioclastic wackestone to packstone limestone

IGNEOUS

dark reddish to purplish brown, with green vesicles, with very fine crystalline to ROCK aphanitic texture

\section{B - Lower part}

Figure 5.--Stratigraphic section

for well 161 - continued. 


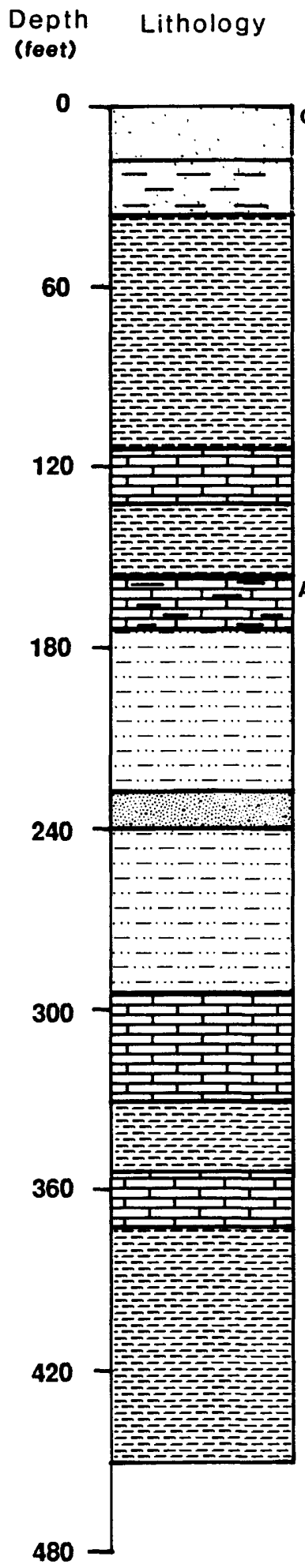

\section{QUARTZ SAND DEPOSITS \\ CLAYEY \\ SANDSTONE}

CLAYSTONE

LIMESTONE

CLAYSTONE

ARGILLACEOUS LIMESTONE

SILTSTONE

GRAVEL AND PEBBLES

SILTSTONE

LIMESTONE

CLAYSTONE

LIMESTONE

CLAYSTONE reddish orange, medium to coarse grained, moderate to good sorting, poorly consolidated, with clay and minor volcanic pebbles

predominantly brownish red, medium to coarsed grained, well indurated

brownish yellow to purple, well indurated, moderately to strongly calcareous, interbedded with silt, sand, gravel, pebbles, and yellowish brown, well indurated, moderately calcareous and terrigenious, sandy limestone

creamy white to pale green, well indurated, with biosparite (microfauna) locally with coarse sand and pebbles

dark brown to orange brown, silty, well indurated

creamy white, pale green, well indurated, grading to strongly calcareous well indurated claystone, locally silty

moderate brown clayey, strongly calcareous, well indurated, locally with sand and pebbles and interbedded claystone

coarse volcanic material in quartzose fraction sand matrix

pale to moderate yellowish brown, clayey, well indurated, locally strongly calcareous, locally sandy, with spare patches of clayey altered limestone

dense quasi-lithographic, locally strongly calcareous, highly clayey

reddish brown silty, well indurated, lenses of altered clayey limestone

pale creamy brown, white mottled, silty, clayey, highly altered, with carbonacious microfauna

reddish brown, well indurated with isolated altered clayey limestone, locally strongly calcareous and silty

\section{A - Upper part}

Figure 6.--Stratigraphic section for well 162, upper part (A) and lower part (B). 


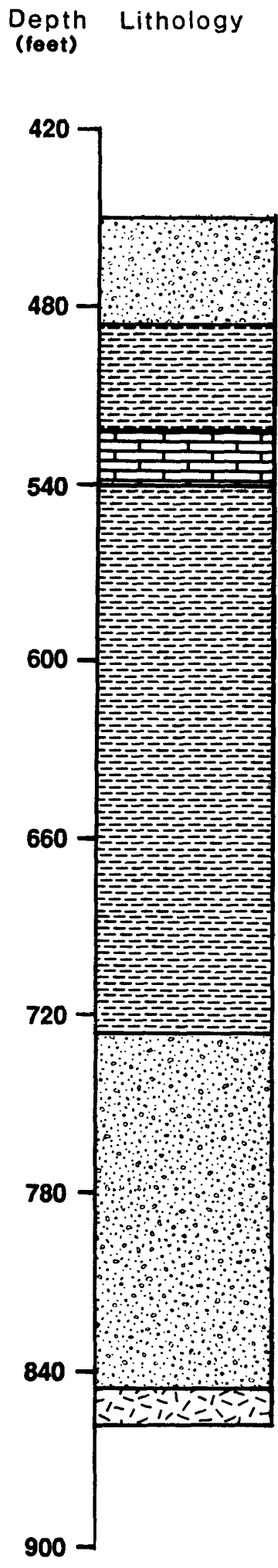

GRAVEL AND

volcanic material, locally with cobbles in a clayey coarse volcanic and quartzose PEBBLES creamy white limestone

CLAYSTONE

reddish brown, slightly calcareous, well indurated

LMESTONE

CLAYSTONE

moderate to reddish brown to pale brown and pale green, well indurated with zones of dayey altered limestone, siltstone and very coarse to pebbly quartzose sand

pale brown and pale green, highly clayey altered limestone, locally with sandy siltstone

volcanic material in a clayey to very coarse sandy matrix

\section{B - Lower part}

Figure 6.--Stratigraphic section

for well 162 - continued. 


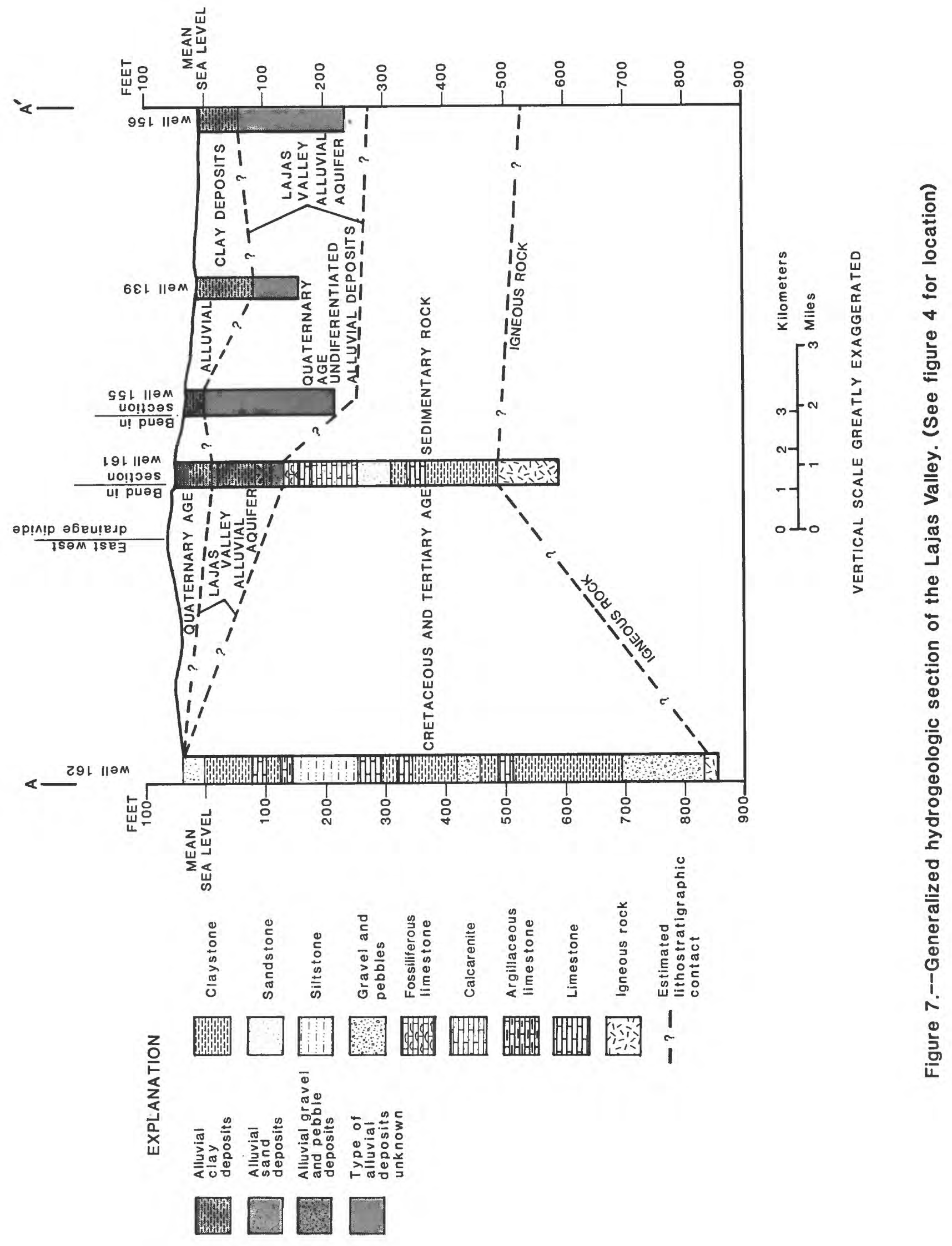


exist between the hydraulic characteristics of the alluvial deposits and the consolidated sedimentary rock. Because of this, the sedimentary rock could be considered a distinct aquifer. Geohydrologic data for the sedimentary rock deposits in Lajas Valley are available for only two deep test wells. Therefore, in this report, the discussions of the Lajas Valley aquifer are of the alluvial deposits. Only where sufficient data were collected is reference made to the occurrence, availability, and quality of the water in the sedimentary rock.

There are few data showing the thickness of the alluvial aquifer or its upper clay confining unit throughout the valley. Test-hole drilling indicate that the base of the aquifer occurs at depths greater than 210 feet in the eastern part of the valley. Cores collected from well 162 indicated that the alluvial deposits pinch out laterally, exposing the sedimentary rock at land surface. Cuttings and cores collected while drilling, and the depth below land surface that ground water was first encountered, indicated that the top of the Lajas Valley alluvial aquifer ranged from 27 to about 90 feet below land surface (fig. 7, table 1).

\section{Movement of Ground Water}

The movement of water within the aquifer is complex. Water levels in wells completed at discrete zones within the alluvial deposits at the three batteries of test wells indicated a downward vertical- flow component at these sites (fig. 8). Elsewhere in the valley, it was difficult to document a vertical-flow component because most privately owned wells have been screened throughout the entire well bore. Water levels in these and other wells that are open to a substantial section of the aquifer, represent a composite head. Therefore, vertical and horizontal ground-water flow pa:terns in most of the study area are discussed in general terms only. It should be noted that these two flow components can vary greatly depending on the part of the aquifer being evaluated.

Data collected from wells 161 and 162 indicated that there was no significant difference between heads in the sedimentary rock and those in lower parts of the alluvial deposits. Therefore, even though some wells in the Lajas Valley were drilled into the sedimentary rock, the water levels in these wells were considered representative of water levels in the alluvial deposits.

The downward vertical ground-water gradient documented at each well battery (fig. 8) may be due to the nonhomogeneous nature of the alluvial material. Cores collected from well 161 indicated that coarse-grain sand lenses interlayered with silty-clay occurred near the base of the alluvial deposits (fig. 5). The coarse-grain sand lenses had a much higher hydraulic conductivity than shallower alluvial deposits, and wells screened in these sands tended to have larger yields. The lower heads near the base of the aquifer may be the result of pumping from wells screened in the deeper alluvial deposits. 
Table 1.--Depth to the first water-bearing zone in test holes and static water level in cased wells [units - NA, data not available: +, indicates water level above land surface]

\begin{tabular}{cccc}
\hline $\begin{array}{c}\text { Well } \\
\text { number } \\
\text { (appendix) }\end{array}$ & $\begin{array}{l}\text { Depth of } \\
\text { test hole } \\
\text { (feet) }\end{array}$ & $\begin{array}{c}\text { Depth to first } \\
\text { water-bearing zone } \\
\text { (feet) }\end{array}$ & $\begin{array}{c}\text { Depth to static water level } \\
\text { in tightly cased well } \\
\text { (feet) }\end{array}$ \\
\hline 138 & 212 & $137-138$ & 21.00 \\
139 & 172 & $87-92$ & 0.50 \\
151 & 25 & NA & 5.00 \\
152 & 40 & 27 & 3.00 \\
153 & 50 & 27 & 3.00 \\
154 & 110 & 27 & 3.00 \\
155 & 247 & 27 & 25.00 \\
156 & 247 & $52-57$ & 1.50 \\
157 & 101 & 52 & +2.78 \\
158 & 59 & 52 & +2.80 \\
159 & 47 & 47 & +2.81 \\
\hline
\end{tabular}

1 Test holes drilled with augers: depth to first water-bearing zone during drilling determined from changes in auger speed and visual inspection of sample cuttings. Depth to first water could be in error plus or minus 5 feet. 


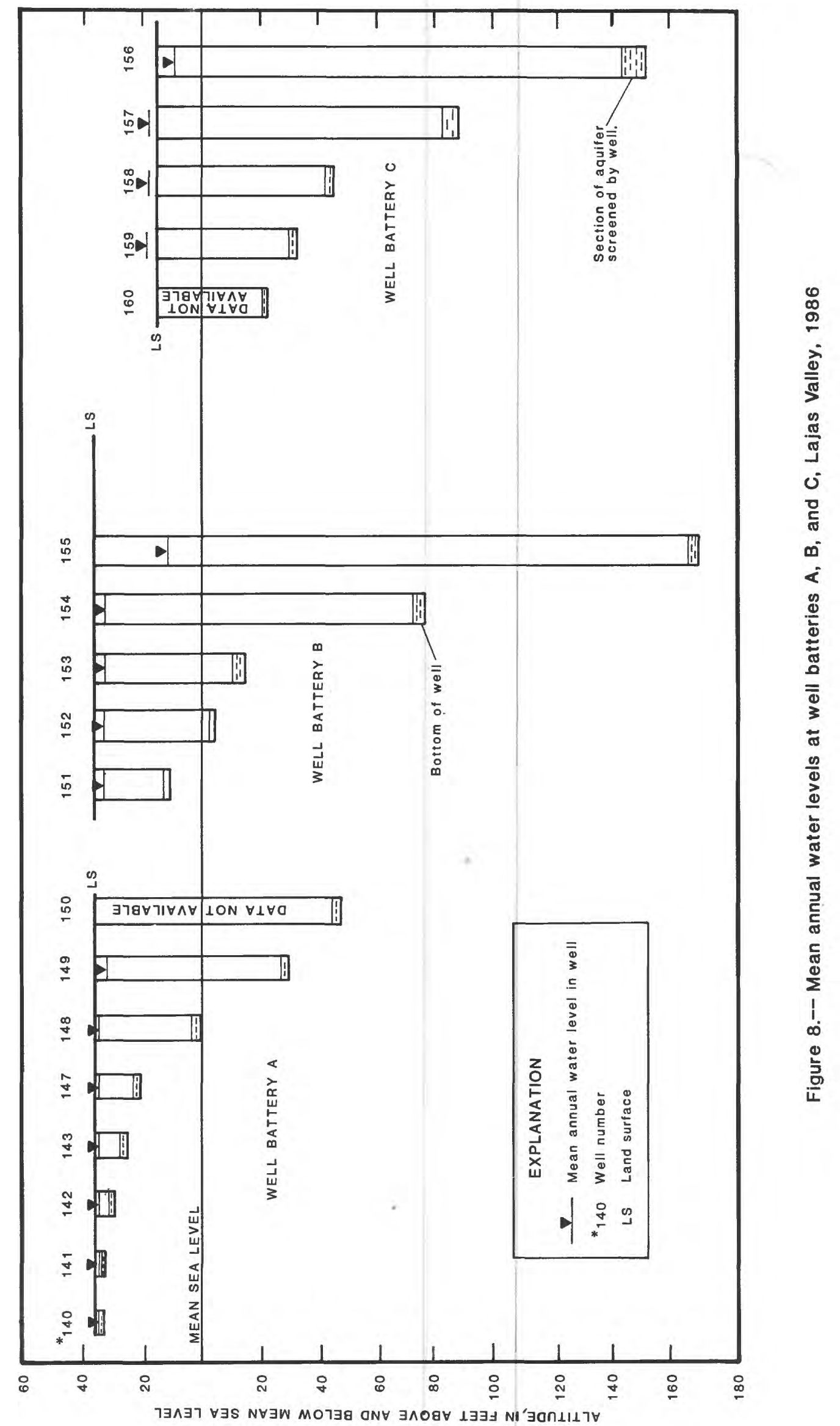




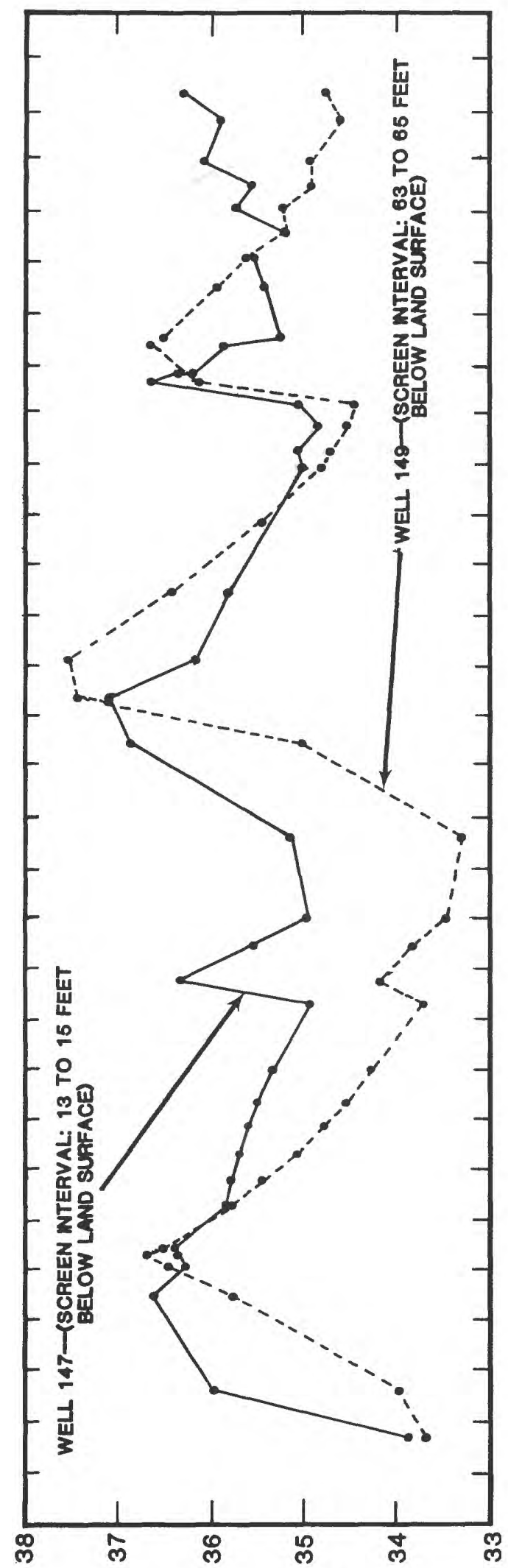

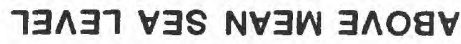



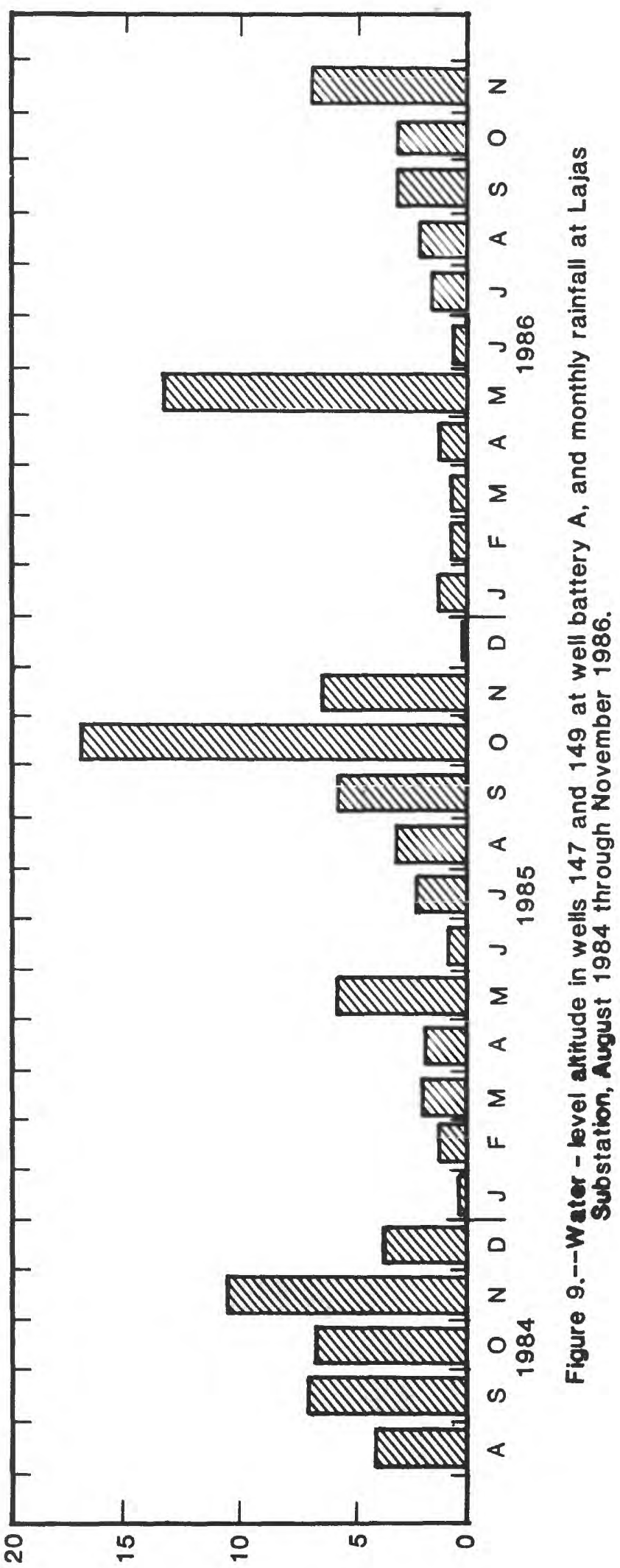

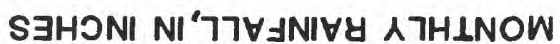




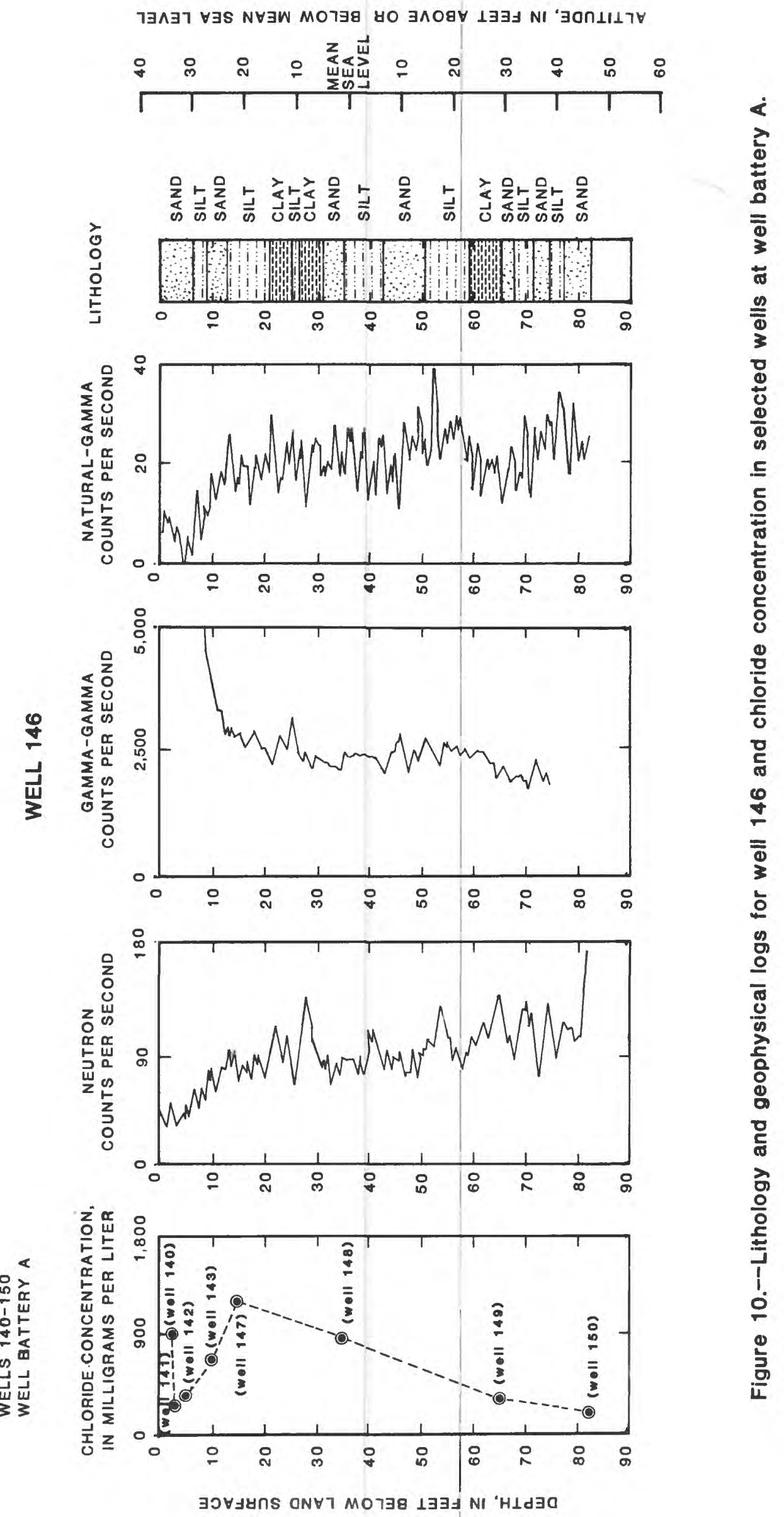


A seasonal reversal in the downward ground-water flow was documented at well battery A (fig. 9). This reversal of vertical gradient coincides with periods of heavy rainfall. The driller's log and borehole geophysical data (well 146, well battery A, fig. 10) indicated that well 149 was screened in a sandy material, and well 147 was screened in a much shallower silty clay. If there was good hydraulic connection between the sand lenses and the coarse-grain alluvial fan material, then, during heavy rainfall events, recharge may occur more rapidly in the permeable sand lenses than in the silty-clay material.

The altitude of the potentiometric surface of the Lajas Valley alluvial aquifer is more than $\mathbf{5 0}$ feet above mean sea level in the northern and southern parts of the valley, about 12 feet above mean sea level in the central part of the valley, and is approximately at sea level near Bahía de Boquerón (fig. 11). The principle direction of horizontal ground-water flow is from the foothills toward the center of the valley and then either east to the Bahía de Guánica or west to Bahía de Boquerón.

Although long-term fluctuations in the potentiometric surface of the Lajas Valley aquifer cannot be evaluated because of the lack of historical data, seasonal fluctuations in the potentiometric surface are evident (fig. 12). Water-level data collected from 1981 to 1986 indicated that generally heads begin to decline in December or January and reach a low in June, July, or August. Recovery of the potentiometric surface usually begins in September. The greatest seasonal change in head in well 105 during the 5-year period from 1982 to 1986 was 2 feet. The maximum change in head in well 149 during a 2.5 -year period, from 1984 to 1986 was approximately 4.5 feet (fig. 9).

The Lajas Valley aquifer is recharged by streamflow and rainfall. Anderson (1977) estimated the annual recharge to the aquifer to be about 2 inches. Most of this recharge occurs through the coarse grain alluvial fan deposits that lie near the edge of the alluvial valley. In the central part of the valley, recharge from rainfall is limited by the less permeable clays near the surface of the alluvial deposits.

Discharge of ground water can occur through pumpage, evapotranspiration, and subsurface seepage. Subsurface seepage occurs at Laguna Cartagena, along the extensive drainage canal system, and at the mangrove swamp at Boquerón (Anderson, 1977). Subsurface seepage also occurs in the form of base flow to Bahía de Boquerón in the western part of the valley and Río Loco and Bahía de Guánica in the eastern part of the valley.

\section{Availability of Ground Water}

Ground-water availability is a function of the ability of an aquifer to transmit, store, and release water to wells. Transmissivity is a measure of the aquifer's ability to transmit water and is a product of the aquifer's hydraulic conductivity and the aquifer thickness. The storage coefficient 


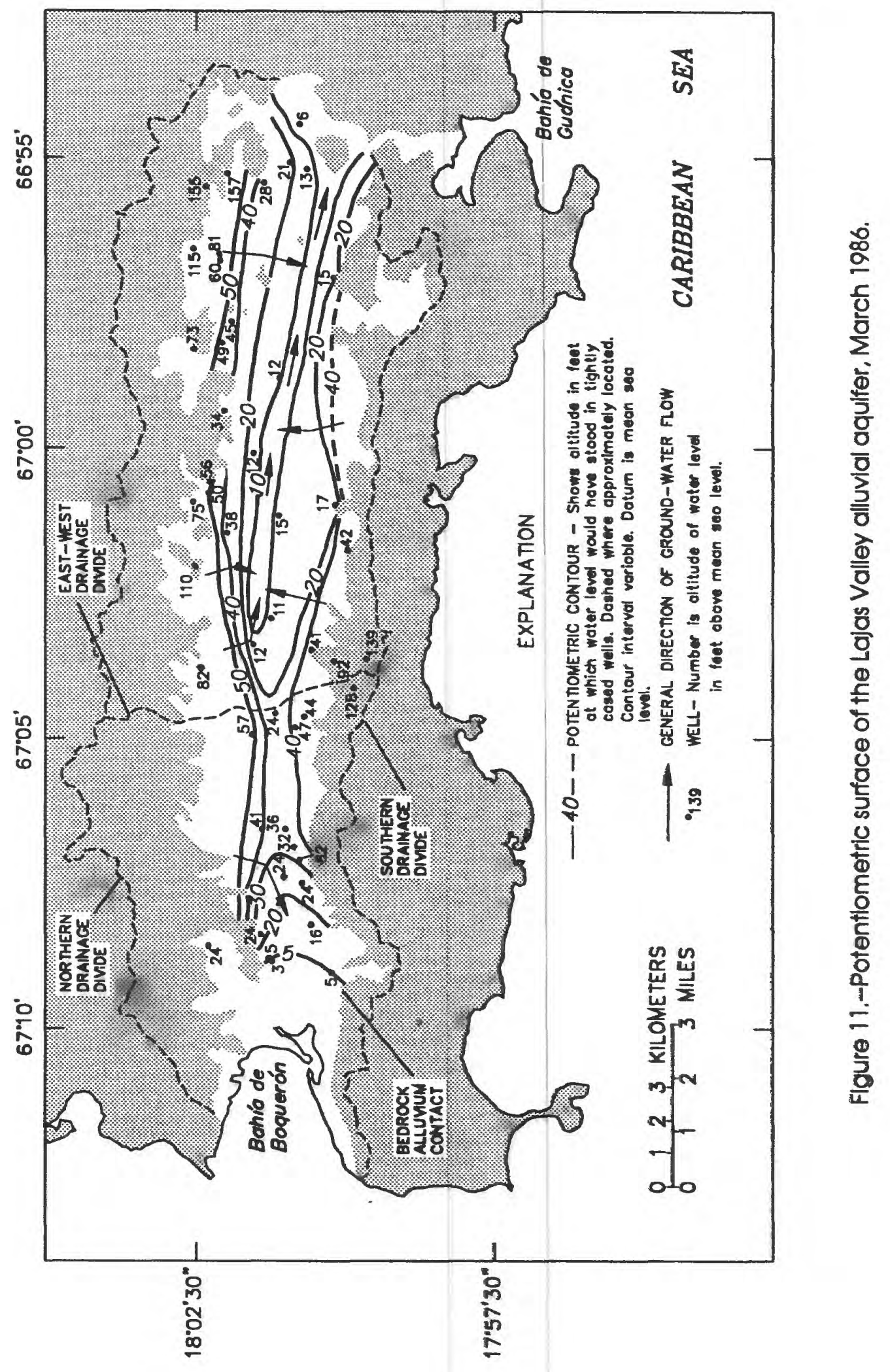




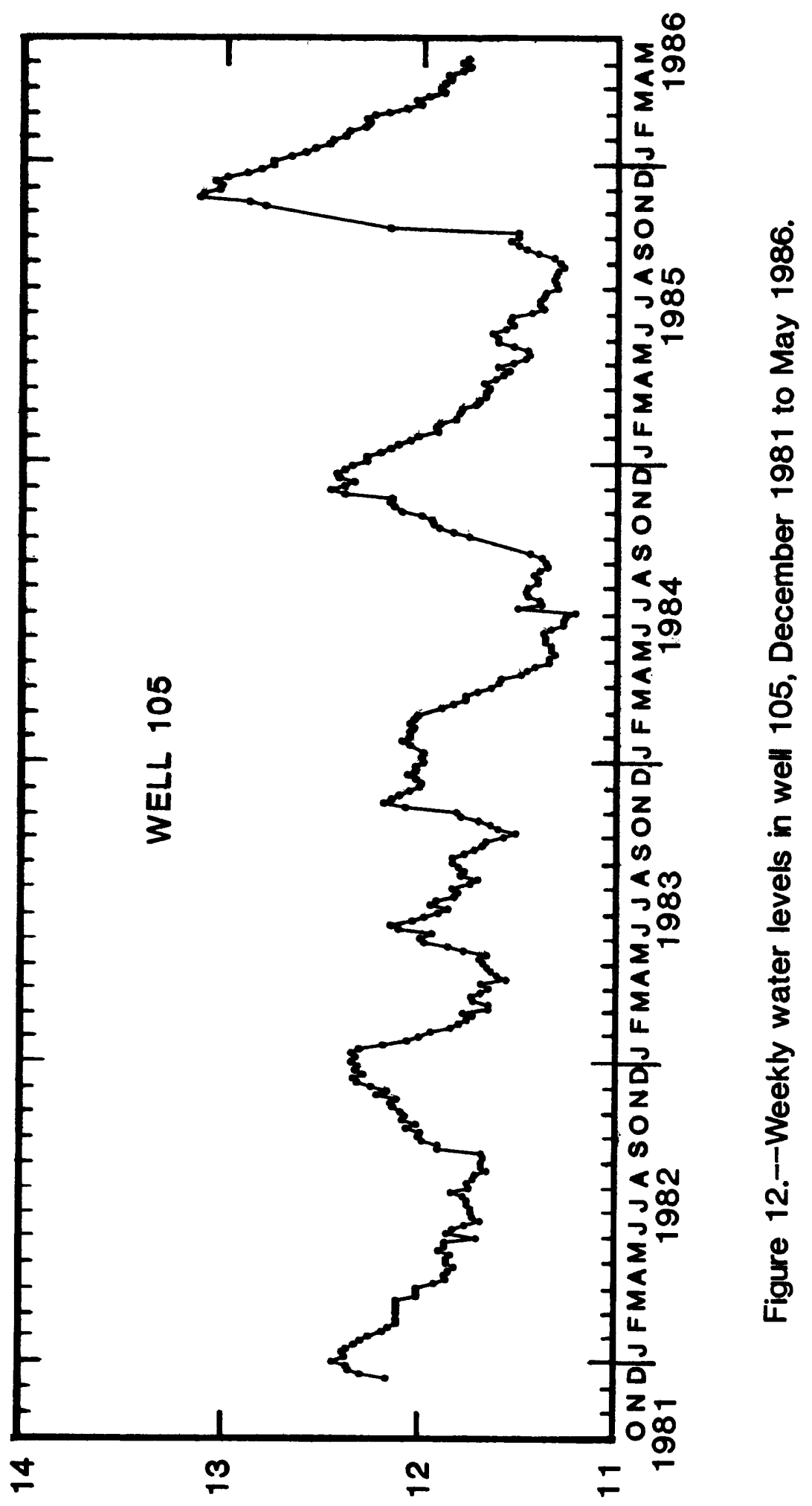






is the volume of water an aquifer releases from or takes into storage per unit surface area of the aquifer per unit change in head. The mathematical definitions of these hydraulic characteristics are beyond the scope of this investigation, but are presented in Lohman (1979).

Hydraulic characteristics of the aquifer were determined from an aquifer test conducted at well 73, and specific capacity estimates for selected wells throughout the valley. The aquifer test was conducted in the La Plata basin area of the Lajas Valley (fig. 1). Based on the results of this test, the transmissivity of the aquifer was estimated at $7,500 \mathrm{ft}^{2} / \mathrm{d}$ (feet squared per day) and the storage coefficient of the aquifer was estimated at 0.00093 . Transmissivity values calculated from ten specific-capacity tests ranged from 670 to $8,020 \mathrm{ft}^{2} / \mathrm{d}$ (table 2).

Pumpage data for wells throughout the study area indicated that well yields ranged from 5 to $674 \mathrm{gal} / \mathrm{min}$ (gallons per minute) (appendix). Based on measurements in wells 161 and 162, well yields in the sedimentary rock ranged from 50 to $200 \mathrm{gal} / \mathrm{min}$. Wells in the alluvial material commonly yielded 30 to $100 \mathrm{gal} / \mathrm{min}$ along the southern edge of the valley and 5 to $200 \mathrm{gal} / \mathrm{min}$ in the central part of the valley. Wells screened in the alluvial fan deposits on the northern side of the valley yielded as much as $300 \mathrm{gal} / \mathrm{min}$. Where these alluvial fan deposits are in hydraulic connection with the underlying sedimentary rock, reported yields were as high as $674 \mathrm{gal} / \mathrm{min}$. Wells drilled near the town of Lajas and in the La Plata basin were reported to yield 500 and 674 $\mathrm{gal} / \mathrm{min}$ respectively.

\section{Ground-Water Use}

In 1986 ground-water use in the Lajas Valley was estimated to be $2.95 \mathrm{Mgal} / \mathrm{d}$ (million gallons per day) (table 3). Only 38 of the 160 wells inventoried in the study area were in use in 1986 (appendix). Of the 38 wells in use, only three were municipal wells. The remainder of the wells in use were used for irrigation, watering livestock, or domestic purposes. Many of the inventoried wells had been abandoned because of high chloride concentrations.

\section{Ground-Water Quality}

The suitability of ground water for domestic, agricultural, or industrial use is dependent upon its dissolved mineral content. Much of the dissolved mineral content of ground water is derived from the soil and rocks through which the water passes. The mineral content of ground water also reflects the extent to which saline water in the aquifer has been diluted by freshwater recharge.

Samples were collected from 20 wells in the Lajas Valley and analyzed for principal cations and anions, iron, manganese, barium, and aluminum. The results of these analyses are given in table 4. Water samples from 19 of these wells had dissolved solids or chloride concentrations that exceeded the recommended U.S. Environmental Protection Agency (EPA) drinking water standards 
Table 2.--Transmissivity of the alluvial aquifer estimated from specific capacity data (estimates based on method described by Meyer, 1963)

[units - (gal/min)/ft, gallons per minute per foot of drawdown; $\mathrm{ft}^{2} / \mathrm{d}$, feet squared per day]

\begin{tabular}{ccc}
\hline $\begin{array}{c}\text { Well number } \\
\text { (appendix) }\end{array}$ & $\begin{array}{c}\text { Specific capacity } \\
{[(\mathrm{gal} / \mathrm{min}) / \mathrm{ft}]}\end{array}$ & $\begin{array}{c}\text { Transmissivity } \\
\left(\mathrm{ft}^{2} / \mathrm{d}\right)\end{array}$ \\
\hline 30 & 6 & 1,740 \\
31 & 20 & 7,350 \\
36 & 25 & 8,020 \\
45 & 8 & 2,406 \\
53 & 5 & 1,340 \\
71 & 5 & 1,340 \\
100 & 7 & 2,005 \\
102 & 2 & 670 \\
103 & 3 & 935 \\
105 & 3 & 935 \\
\hline
\end{tabular}

Table 3.--Estimated ground-water use in Lajas Valley, 1986

Type of use

Number of wells

Estimated water use (million gallons per day)

\begin{tabular}{lcc}
\hline Agricultural & 24 & 2.00 \\
Domestic & 11 & 0.16 \\
Municipal & $\underline{3}$ & $\underline{0.79}$ \\
Total & 38 & 2.95 \\
\hline
\end{tabular}


Table 4.--Chemical analyses of ground water in Lajas Valley

[units - $\mathrm{mg} / \mathrm{L}$, milligrams per liter]

\begin{tabular}{|c|c|c|c|c|c|c|c|c|c|c|c|c|c|}
\hline $\begin{array}{l}\text { Well } \\
\text { number } \\
\text { (appen- } \\
\text { dix) }\end{array}$ & $\begin{array}{c}\text { Date } \\
\text { of } \\
\text { sampling }\end{array}$ & $\begin{array}{c}\text { Depth } \\
\text { of } \\
\text { well } \\
\text { sampled } \\
\text { (feet) }\end{array}$ & $\begin{array}{l}\text { Type } \\
\text { of } \\
\text { casing }\end{array}$ & $\begin{array}{l}\text { Silica } \\
\text { dis- } \\
\text { solved } \\
\text { (mg/L } \\
\text { as Si) }\end{array}$ & $\begin{array}{l}\text { Cal- } \\
\text { cium } \\
\text { dis- } \\
\text { solved } \\
\text { (mg/L } \\
\text { as } \mathrm{Ca} \text { ) }\end{array}$ & $\begin{array}{l}\text { Magne- } \\
\text { sium } \\
\text { dis- } \\
\text { solved } \\
\text { (mg/L } \\
\text { as } \mathrm{Mg} \text { ) }\end{array}$ & $\begin{array}{l}\text { Sodium } \\
\text { dis- } \\
\text { solved } \\
\text { (mg/L } \\
\text { as } \mathrm{Na} \text { ) }\end{array}$ & $\begin{array}{l}\text { Potas- } \\
\text { sium } \\
\text { dis- } \\
\text { solved } \\
\text { (mg/L } \\
\text { as K) }\end{array}$ & $\begin{array}{l}\text { Alka- } \\
\text { linity } \\
\text { field } \\
\text { (mg/. } \\
\text { as } \\
(\mathrm{CaCO} 3)\end{array}$ & $\begin{array}{l}\text { Sul- } \\
\text { fate } \\
\text { dis- } \\
\text { solved } \\
\text { (mg/L } \\
\text { as SO4) }\end{array}$ & $\begin{array}{l}\text { Chlo- } \\
\text { ride } \\
\text { dis- } \\
\text { solved } \\
\text { (mg/L } \\
\text { as Cl) }\end{array}$ & $\begin{array}{l}\text { Fhuo- } \\
\text { ride } \\
\text { dis- } \\
\text { solved } \\
\text { (mg/L } \\
\text { as F) }\end{array}$ & $\begin{array}{l}\text { Nit- } \\
\text { rate } \\
\text { dis- } \\
\text { solved } \\
\text { (mg/L } \\
\text { as NO3) }\end{array}$ \\
\hline 012 & $06-19-86$ & 2 & OPEN HOLE & 25 & 10 & 9.4 & 42 & 4.0 & 51 & 19 & 57 & 0.3 & 4.50 \\
\hline 034 & $06-20-86$ & 80 & STEEL & 35 & 120 & 98.0 & 400 & 2.4 & 426 & 190 & 640 & 0.8 & 27.00 \\
\hline 036 & $06-20-86$ & 111 & STEEL & 44 & 94 & 44.0 & 51 & 0.6 & 379 & 97 & 42 & 0.4 & 5.30 \\
\hline 051 & $06-20-86$ & 32 & STEEL & 42 & 71 & 30.0 & 120 & 0.7 & 403 & 78 & 55 & 0.6 & 5.20 \\
\hline 085 & $06-20-86$ & 40 & STEEL & 40 & 43 & 35.0 & 570 & 1.2 & 661 & 180 & 450 & 0.6 & 5.60 \\
\hline 138 & $06-19-86$ & 170 & PLASTIC & 31 & 280 & 500.0 & 1,500 & 3.3 & 544 & 1,300 & 3,200 & 0.3 & 0.23 \\
\hline 139 & $06-18-86$ & 154 & PLASTIC & 29 & 600 & 590.0 & 3,500 & 3.9 & 315 & 2,100 & 6,400 & 0.4 & 1.50 \\
\hline 140 & $06-19-86$ & 2 & PLASTIC & 24 & 560 & 280.0 & 870 & 23.0 & 963 & 2,100 & 960 & 0.3 & 0.10 \\
\hline 141 & $07-18-86$ & 3 & PLASTIC & 35 & 330 & 100.0 & 260 & 6.5 & 1,095 & 490 & 210 & 0.3 & 0.10 \\
\hline 147 & $06-19-86$ & 15 & PLASTIC & 9 & 500 & 419.0 & 1,099 & 2.2 & 633 & 3,300 & 2,400 & 0.6 & 0.15 \\
\hline 148 & $06-19-86$ & 35 & PLASTIC & 17 & 270 & 370.0 & 1,600 & 3.3 & 506 & 430 & 850 & 0.8 & 0.10 \\
\hline 149 & $06-19-86$ & 65 & PLASTIC & 22 & 100 & 120.0 & 310 & 6.7 & 204 & 900 & 230 & 0.3 & 0.10 \\
\hline 151 & $06-19-86$ & 25 & PLASTIC & 16 & 480 & 490.0 & 4,200 & 3.5 & 282 & 4,600 & 5,000 & 0.4 & 0.10 \\
\hline 153 & $06-19-86$ & 50 & PLASTIC & 29 & 62 & 100.0 & 1,400 & 1.6 & 585 & 960 & 1,800 & 0.5 & 0.10 \\
\hline 155 & $06-19-86$ & 203 & PLASTIC & 16 & 780 & 680.0 & 1,900 & 5.7 & 263 & 1,100 & 5,800 & 0.2 & 0.10 \\
\hline 156 & $06-18-86$ & 166 & PLASTIC & 28 & 140 & 67.0 & 830 & 3.6 & 431 & 500 & 1,100 & 0.5 & 0.10 \\
\hline 159 & $06-18-86$ & 47 & PLASTIC & 28 & 38 & 23.0 & 690 & 0.9 & 682 & 130 & 610 & 1.1 & 0.10 \\
\hline 160 & $06-18-86$ & 37 & PLASTIC & 24 & 190 & 120.0 & 1,700 & 3.1 & 643 & 640 & 2,700 & 0.5 & 0.10 \\
\hline 161 & $03-10-87$ & 17 & OPEN HOLE & 30 & 51 & 30.0 & 259 & 1.0 & 517 & 219 & 70 & 0.5 & 0.39 \\
\hline 161 & $03-10-87$ & 60 & OPEN HOLE & 33 & 65 & 39.0 & 670 & 0.6 & 559 & 400 & 610 & 0.5 & 1.70 \\
\hline 161 & $03-10-87$ & 184 & OPEN HOLE & 29 & 130 & 100.0 & 610 & 2.2 & 475 & 460 & 900 & 0.6 & 0.42 \\
\hline 161 & $03-10-87$ & 236 & OPEN HOLE & 28 & 200 & 179.0 & 1,099 & 4.3 & 395 & 680 & 2,000 & 0.5 & 0.19 \\
\hline 161 & $03-10-87$ & 346 & OPEN HOLE & 72 & 330 & 230.0 & 1,100 & 6.6 & 353 & 860 & 2,400 & 0.6 & 0.11 \\
\hline 162 & $03-31-87$ & 68 & OPEN HOLE & 19 & 66 & 39.0 & 340 & 3.8 & 250 & 85 & 550 & 0.3 & 0.40 \\
\hline 162 & $04-01-87$ & 476 & OPEN HOLE & 10 & 73 & 53.0 & 510 & 12.0 & 203 & 80 & 929 & 0.5 & 0.42 \\
\hline
\end{tabular}


Table 4.-Chemical analyses of ground water in Lajas Valley--Continued [units - $m g / L$, milligrams per liter, $\mu \mathrm{S} / \mathrm{cm}$, microsiemens per centimeter at 25 degrees Celsius; deg C, degrees Celcius; $\mu g / L$, micrograms per liter, NA, data not available]

\begin{tabular}{|c|c|c|c|c|c|c|c|c|c|c|c|}
\hline $\begin{array}{c}\text { Well } \\
\text { number } \\
\text { (appen- } \\
\text { dix) }\end{array}$ & $\begin{array}{c}\text { Depth } \\
\text { of } \\
\text { well } \\
\text { sampled } \\
\text { (feet) }\end{array}$ & $\begin{array}{l}\text { Dis- } \\
\text { solved } \\
\text { solids } \\
\text { (mg/L) }\end{array}$ & $\begin{array}{l}\text { Hand- } \\
\text { ness } \\
\text { (mg/L } \\
\text { as } \\
\mathrm{CaCO3} \text { ) }\end{array}$ & $\begin{array}{l}\text { Hand- } \\
\text { ness } \\
\text { noncar- } \\
\text { bonate } \\
\text { (mg/L } \\
\mathrm{CaCO3)}\end{array}$ & $\begin{array}{l}\text { Spe } \\
\text { cific } \\
\text { con- } \\
\text { duct- } \\
\text { ance } \\
(\mu S / c m)\end{array}$ & $\begin{array}{l}\text { pH } \\
\text { (units) }\end{array}$ & $\begin{array}{l}\text { Temp- } \\
\text { ature } \\
(\operatorname{deg} C)\end{array}$ & $\begin{array}{c}\text { Iron } \\
\text { dis- } \\
\text { solved } \\
(\mu g / L \\
\text { as } \mathrm{Fe})\end{array}$ & $\begin{array}{l}\text { Man- } \\
\text { ganese } \\
\text { dis- } \\
\text { solved } \\
\text { ( } 1 \mathrm{~g} / \mathrm{L} \\
\text { as } \mathrm{Mn})\end{array}$ & $\begin{array}{l}\text { Barium } \\
\text { dis- } \\
\text { solved } \\
(\mu g / L \\
\text { as } \mathrm{Ba})\end{array}$ & $\begin{array}{l}\text { Alu- } \\
\text { minum } \\
\text { dis- } \\
\text { solved } \\
(\mu g / L \\
\text { as } \mathrm{Al})\end{array}$ \\
\hline $\begin{array}{l}012 \\
034\end{array}$ & $\begin{array}{r}2 \\
80\end{array}$ & $\begin{array}{r}200 \\
1,700\end{array}$ & $\begin{array}{c}64 \\
703\end{array}$ & $\begin{array}{r}13 \\
264\end{array}$ & $\begin{array}{r}379 \\
3,130\end{array}$ & $\begin{array}{l}6.3 \\
7.7\end{array}$ & $\begin{array}{l}27.0 \\
26.5\end{array}$ & $\begin{array}{l}19 \\
20\end{array}$ & $\begin{array}{l}13 \\
10\end{array}$ & $\begin{array}{l}\text { NA } \\
\text { NA }\end{array}$ & $\begin{array}{l}\text { NA } \\
\text { NA }\end{array}$ \\
\hline $\begin{array}{l}036 \\
051\end{array}$ & $\begin{array}{r}111 \\
32\end{array}$ & $\begin{array}{l}570 \\
640\end{array}$ & $\begin{array}{l}416 \\
301\end{array}$ & $\begin{array}{r}84 \\
0\end{array}$ & $\begin{array}{r}955 \\
1,030\end{array}$ & $\begin{array}{l}7.2 \\
7.3\end{array}$ & $\begin{array}{l}25.5 \\
26.5\end{array}$ & $\begin{array}{r}3 \\
48\end{array}$ & $\begin{array}{l}3 \\
1\end{array}$ & $\begin{array}{l}\text { NA } \\
\text { NA }\end{array}$ & $\begin{array}{l}\text { NA } \\
\text { NA }\end{array}$ \\
\hline $\begin{array}{l}085 \\
138\end{array}$ & $\begin{array}{r}40 \\
170\end{array}$ & $\begin{array}{l}1,700 \\
7,100\end{array}$ & $\begin{array}{r}251 \\
2,782\end{array}$ & $\begin{array}{r}0 \\
2,229\end{array}$ & $\begin{array}{r}2,840 \\
10,600\end{array}$ & $\begin{array}{l}7.7 \\
7.3\end{array}$ & $\begin{array}{l}28.0 \\
26.0\end{array}$ & $\begin{array}{l}10 \\
50\end{array}$ & $\begin{array}{l}30 \\
60\end{array}$ & $\begin{array}{l}\text { NA } \\
\text { NA }\end{array}$ & $\begin{array}{l}\text { NA } \\
\text { NA }\end{array}$ \\
\hline $\begin{array}{l}139 \\
140\end{array}$ & $\begin{array}{r}154 \\
2\end{array}$ & $\begin{array}{c}13,230 \\
5,400\end{array}$ & $\begin{array}{l}3,926 \\
2,551\end{array}$ & $\begin{array}{l}3,606 \\
1,602\end{array}$ & $\begin{array}{r}19,300 \\
6,500\end{array}$ & $\begin{array}{l}7.0 \\
6.9\end{array}$ & $\begin{array}{l}28.0 \\
26.5\end{array}$ & $\begin{array}{r}140 \\
2,600\end{array}$ & $\begin{array}{r}60 \\
12,000\end{array}$ & $\begin{array}{l}\text { NA } \\
\text { NA }\end{array}$ & $\begin{array}{l}\text { NA } \\
\text { NA }\end{array}$ \\
\hline $\begin{array}{l}141 \\
147\end{array}$ & $\begin{array}{r}3 \\
15\end{array}$ & $\begin{array}{l}1,470 \\
8,100\end{array}$ & $\begin{array}{l}1,236 \\
2,974\end{array}$ & $\begin{array}{r}270 \\
2,456\end{array}$ & $\begin{array}{l}3,200 \\
7,470\end{array}$ & $\begin{array}{l}6.8 \\
7.0\end{array}$ & $\begin{array}{l}26.5 \\
25.5\end{array}$ & $\begin{array}{r}24,000 \\
230\end{array}$ & $\begin{array}{r}11,000 \\
4,600\end{array}$ & $\begin{array}{l}\text { NA } \\
\text { NA }\end{array}$ & $\begin{array}{l}\text { NA } \\
\text { NA }\end{array}$ \\
\hline $\begin{array}{l}148 \\
149\end{array}$ & $\begin{array}{l}35 \\
65\end{array}$ & $\begin{array}{l}3,000 \\
1,800\end{array}$ & $\begin{array}{r}2,197 \\
744\end{array}$ & $\begin{array}{r}1,686 \\
544\end{array}$ & $\begin{array}{l}9,200 \\
2,550\end{array}$ & $\begin{array}{l}7.0 \\
6.4\end{array}$ & $\begin{array}{l}25.5 \\
25.5\end{array}$ & $\begin{array}{r}810 \\
1,200\end{array}$ & $\begin{array}{l}2,600 \\
2,800\end{array}$ & $\begin{array}{l}\text { NA } \\
\text { NA }\end{array}$ & $\begin{array}{l}\text { NA } \\
\text { NA }\end{array}$ \\
\hline $\begin{array}{l}151 \\
153\end{array}$ & $\begin{array}{l}25 \\
50\end{array}$ & $\begin{array}{r}15,000 \\
4,700\end{array}$ & $\begin{array}{r}3,215 \\
566\end{array}$ & $\begin{array}{r}2,948 \\
0\end{array}$ & $\begin{array}{r}19,200 \\
7,320\end{array}$ & $\begin{array}{l}7.5 \\
7.5\end{array}$ & $\begin{array}{l}27.0 \\
27.0\end{array}$ & $\begin{array}{r}220 \\
70\end{array}$ & $\begin{array}{l}940 \\
310\end{array}$ & $\begin{array}{l}\text { NA } \\
\text { NA }\end{array}$ & $\begin{array}{l}\text { NA } \\
\text { NA }\end{array}$ \\
\hline $\begin{array}{l}155 \\
156\end{array}$ & $\begin{array}{l}203 \\
166\end{array}$ & $\begin{array}{r}10,000 \\
2,900\end{array}$ & $\begin{array}{r}4,747 \\
625\end{array}$ & $\begin{array}{r}4,491 \\
189\end{array}$ & $\begin{array}{r}15,400 \\
4,860\end{array}$ & $\begin{array}{l}7.3 \\
7.1\end{array}$ & $\begin{array}{l}26.0 \\
29.5\end{array}$ & $\begin{array}{l}320 \\
260\end{array}$ & $\begin{array}{r}5,400 \\
840\end{array}$ & $\begin{array}{l}\text { NA } \\
\text { NA }\end{array}$ & $\begin{array}{l}\text { NA } \\
\text { NA }\end{array}$ \\
\hline $\begin{array}{l}159 \\
160\end{array}$ & $\begin{array}{l}47 \\
37\end{array}$ & $\begin{array}{l}1,900 \\
5,800\end{array}$ & $\begin{array}{l}190 \\
968\end{array}$ & $\begin{array}{r}0 \\
315\end{array}$ & $\begin{array}{l}3,240 \\
9,210\end{array}$ & $\begin{array}{l}7.4 \\
7.1\end{array}$ & $\begin{array}{l}29.0 \\
26.5\end{array}$ & $\begin{array}{r}30 \\
310\end{array}$ & $\begin{array}{r}10 \\
2,400\end{array}$ & $\begin{array}{l}\text { NA } \\
\text { NA }\end{array}$ & $\begin{array}{l}\text { NA } \\
\text { NA }\end{array}$ \\
\hline $\begin{array}{l}161 \\
161\end{array}$ & $\begin{array}{l}17 \\
60\end{array}$ & $\begin{array}{r}970 \\
2,200\end{array}$ & $\begin{array}{l}250 \\
320\end{array}$ & $\begin{array}{l}0 \\
0\end{array}$ & $\begin{array}{l}1,450 \\
3,410\end{array}$ & $\begin{array}{l}8.2 \\
8.0\end{array}$ & $\begin{array}{l}28.0 \\
27.0\end{array}$ & $\begin{array}{r}4 \\
20\end{array}$ & $\begin{array}{l}43 \\
10\end{array}$ & $\begin{array}{r}20 \\
100\end{array}$ & $\begin{array}{l}10 \\
10\end{array}$ \\
\hline $\begin{array}{l}161 \\
161\end{array}$ & $\begin{array}{l}184 \\
236\end{array}$ & $\begin{array}{l}2,500 \\
4,399\end{array}$ & $\begin{array}{r}740 \\
1,200\end{array}$ & $\begin{array}{l}260 \\
850\end{array}$ & $\begin{array}{l}3,980 \\
6,930\end{array}$ & $\begin{array}{l}8.1 \\
7.9\end{array}$ & $\begin{array}{l}26.0 \\
25.5\end{array}$ & $\begin{array}{l}10 \\
80\end{array}$ & $\begin{array}{r}30 \\
230\end{array}$ & $\begin{array}{l}100 \\
100\end{array}$ & $\begin{array}{l}10 \\
30\end{array}$ \\
\hline $\begin{array}{l}161 \\
162\end{array}$ & $\begin{array}{r}346 \\
68\end{array}$ & $\begin{array}{l}5,200 \\
1,300\end{array}$ & $\begin{array}{r}1,800 \\
330\end{array}$ & $\begin{array}{r}1,400 \\
76\end{array}$ & $\begin{array}{l}7,820 \\
2,410\end{array}$ & $\begin{array}{l}7.8 \\
8.9\end{array}$ & $\begin{array}{l}25.5 \\
32.0\end{array}$ & $\begin{array}{l}30 \\
60\end{array}$ & $\begin{array}{l}80 \\
30\end{array}$ & $\begin{array}{l}100 \\
100\end{array}$ & $\begin{array}{l}10 \\
80\end{array}$ \\
\hline 162 & 476 & 1,799 & 410 & 200 & 3,570 & 7.3 & 28.0 & 30 & 1,299 & 400 & 10 \\
\hline
\end{tabular}


Table 5.--Concentrations of iron, manganese, dissolved solids, and chloride exceeding U.S. Environmental Protection Agency drinking water standards, in ground water from wells in Lajas Valley

[units - $\mu \mathrm{g} / \mathrm{L}$, micrograms per liter, $\mathrm{mg} / \mathrm{L}$, milligrams per liter; < indicates concentration was less than recommended limit; U.S. Environmental Protection Agency drinking water standards for iron, manganese, dissolved solids, and chloride are $300 \mu \mathrm{g} / \mathrm{L}, 50 \mu \mathrm{g} / \mathrm{L}, 500 \mathrm{mg} / \mathrm{L}$, and $250 \mathrm{mg} / \mathrm{L}$, respectively; source: U.S. Environmental Protection Agency, 1973, 1989]

\begin{tabular}{|c|c|c|c|c|}
\hline $\begin{array}{c}\text { Well } \\
\text { number } \\
\text { (appendix) }\end{array}$ & $\begin{array}{l}\text { Iron } \\
(\mu \mathrm{g} / \mathrm{L})\end{array}$ & $\begin{array}{c}\text { Manganese } \\
(\mu \mathrm{g} / \mathrm{L})\end{array}$ & $\begin{array}{l}\text { Dissolved } \\
\text { solids } \\
(\mathrm{mg} / \mathrm{L})\end{array}$ & $\begin{array}{c}\text { Chloride } \\
(\mathrm{mg} / \mathrm{L})\end{array}$ \\
\hline 034 & $<$ & $<$ & 1,700 & 640 \\
\hline 036 & $<$ & $<$ & 570 & $<$ \\
\hline 051 & $<$ & $<$ & 640 & $<$ \\
\hline 085 & $<$ & $<$ & 1,700 & 450 \\
\hline 138 & $<$ & 60 & 7,100 & 3,200 \\
\hline 139 & $<$ & 60 & 13,230 & 6,400 \\
\hline 140 & 2,600 & 12,000 & 5,400 & 960 \\
\hline 141 & 24,000 & 11,000 & 1,470 & $<$ \\
\hline 148 & 810 & 260 & 12,000 & 850 \\
\hline 147 & $<$ & 4,600 & 8,100 & 2,400 \\
\hline 149 & 1,200 & 2,800 & 1,800 & $<$ \\
\hline 151 & $<$ & 940 & 15,000 & 5,000 \\
\hline 153 & $<$ & 310 & 4,700 & 1,800 \\
\hline 155 & 320 & 5,400 & 10,000 & 5,800 \\
\hline 156 & $<$ & 840 & 2,900 & 1,100 \\
\hline 159 & $<$ & $<$ & 1,900 & 610 \\
\hline 160 & 310 & 2,400 & 5,800 & 2,700 \\
\hline${ }^{1} 161 / 17$ & $<$ & $<$ & 970 & $<$ \\
\hline $161 / 60$ & $<$ & $<$ & 2,200 & 610 \\
\hline $161 / 184$ & $<$ & $<$ & 2,500 & 900 \\
\hline $161 / 236$ & $<$ & 230 & 4,399 & 2,000 \\
\hline $161 / 346$ & $<$ & 80 & 5,200 & 240 \\
\hline $162 / 68$ & $<$ & $<$ & 1,300 & 550 \\
\hline $162 / 476$ & $<$ & 1,299 & 1,799 & 929 \\
\hline
\end{tabular}

${ }^{1}$ Number after slash indicates depth at which sample was collected. 
of 500 and $250 \mathrm{mg} / \mathrm{L}$ (milligrams per liter), respectively (table 5) (U.S. Environmental Protection Agency, 1973). Samples from 13 of the wells had concentrations of dissolved iron or manganese that exceeded the recommended EPA drinking water standards of 300 and $50 \mu \mathrm{g} / \mathrm{L}$ (micrograms per liter), respectively (U.S. Environmental Protection Agency, 1986).

Elevated iron and manganese concentrations found in the ground water in the study area might be the result of the dissolution of iron and manganese concentrated in the sediments by organic activity during deposition of the sediments (McGuinness, 1948). The elevated iron and manganese concentrations might also be the result of weathering of magnetite, hematite, and manganese-bearing minerals found in the bedrock ridges surrounding the Lajas Valley.

The high concentration of dissolved solids found in most of the samples were due primarily to high concentrations of sodium and chloride ions. Elevated chloride concentrations in ground water have been reported in the Lajas Valley (Bonnet and Brenes, 1958; Lugo-Lopez, and others, 1959; Vázquez and Vélez, 1967). However, Anderson (1977) reported a decrease in chloride concentrations with an increase in well depth, which has led to speculation that the alluvial deposits may be underlain by deposits containing less mineralized water. To assess the relation between chloride concentration and depth, water samples were collected from wells in the three well batteries and at selected intervals in wells 161 and 162. Analysis of samples collected from wells 161 and 162 indicated an increase in chloride concentration with depth (fig. 13). At well batteries B and C there was a decrease in chloride concentration with depth, to a depth of about 50 feet, but concentrations increased with depth below 50 feet (fig. 14). The higher chloride concentrations at shallow depths at well batteries B and C could reflect the concentrating effect of evapotranspiration. At greater depths, the increase in chloride concentration is probably attributable to connate water that has not been flushed out of the aquifer. The presence of connate water would also be the most likely explanation for the increase in chloride concentration in wells 161 and 162.

The change in chloride concentration with depth at well battery A varies anomalously (figs. 10 and 14). The chloride concentration near land surface (well 140) was higher than that of the next deepest well (well 141). The chloride concentration then began to increase with depth (wells 142,143 , and 147) to a depth of 15 feet. This anomaly is difficult to explain. Perhaps the high chloride concentration in well 140 was due to a high mineral content in the near surface soil zone due to evapotranspiration. The lower chloride concentration in well 141 and the higher chloride concentration in wells 142,143 , and 147 , could be due to the nonhomogeneity of the alluvial deposits (fig. 10). Chloride concentrations decreased with depth in the wells deeper than 15 feet (wells 148, 149 and 150). This decrease may be due to the greater occurrence of coarse sand lenses at these depths (15 to about 80 feet) and the increased potential for flushing of the sand lenses by recharge through 

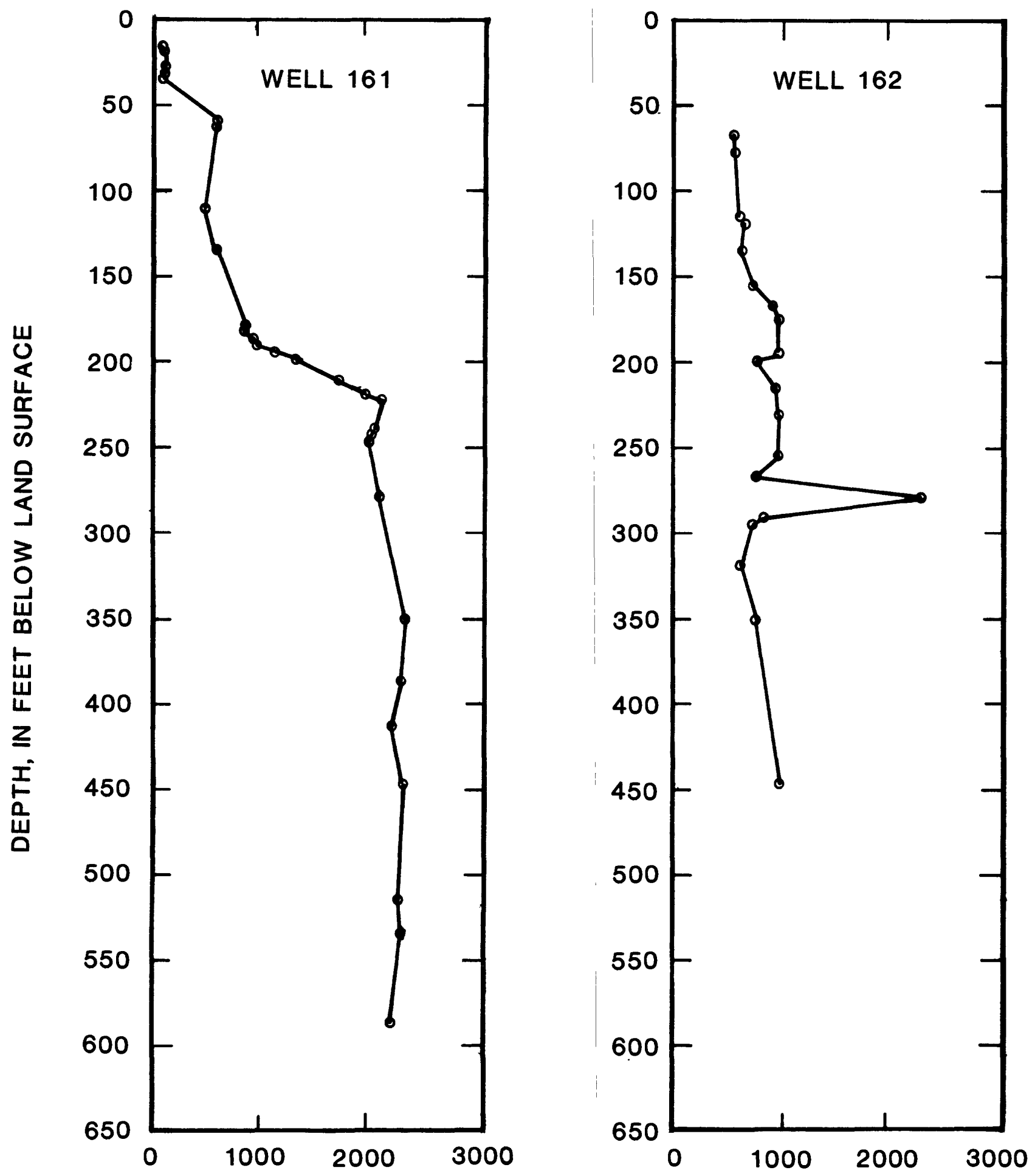

CHLORIDE CONCENTRATION, IN MILLIGRAMS PER LITER

Figure 13.--Chloride concentration with depth for wells 161 and 162, March 1987. 

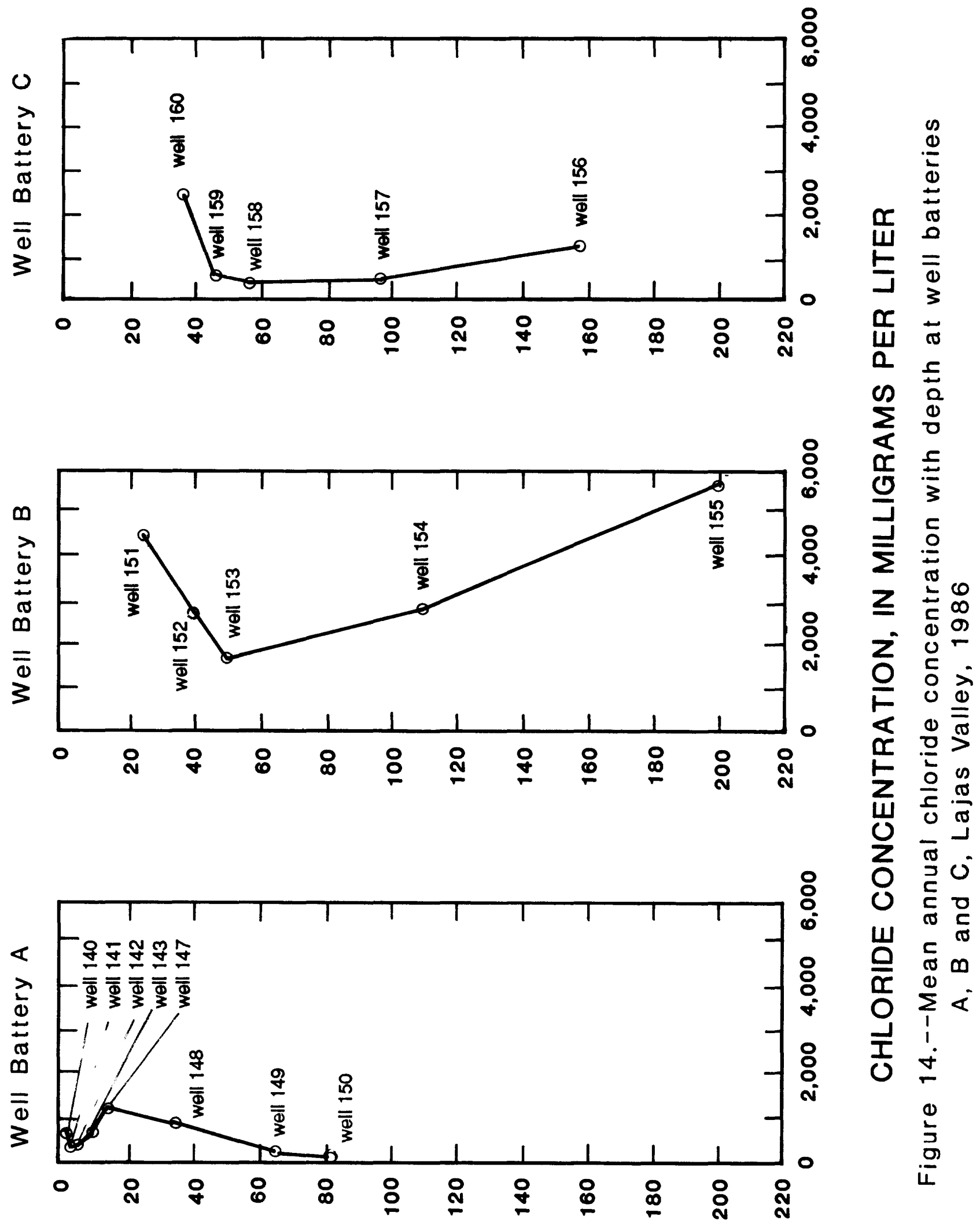
Table 6.--Specific conductance and chloride concentrations in ground water at selected wells in Lajas Valley, March 1986

[units $-\mu \mathrm{S} / \mathrm{cm}$, microsiemens per centimeter at 25 degrees Celsius;

$\mathrm{mg} / \mathrm{L}$, milligrams per liter; ---, indicates data not available;

* indicates sample exceeds 1973 U.S. Environmental Protection

Agency drinking water standard of 250 milligrams per liter for chloride; Source: U.S. Environmental Protection Agency, 1973]

\begin{tabular}{|c|c|c|}
\hline $\begin{array}{c}\text { Well } \\
\text { number } \\
\text { (appendix) }\end{array}$ & $\begin{array}{l}\text { Specific conductance } \\
(\mu \mathrm{S} / \mathrm{cm})\end{array}$ & $\begin{array}{l}\text { Chloride concentration } \\
(\mathrm{mg} / \mathrm{L})\end{array}$ \\
\hline $\begin{array}{l}01 \\
02 \\
03\end{array}$ & $\begin{array}{r}115 \\
690 \\
6,000\end{array}$ & $\begin{array}{r}30 \\
180 \\
* \quad 1,800\end{array}$ \\
\hline $\begin{array}{l}04 \\
05 \\
07\end{array}$ & $\begin{array}{r}490 \\
229 \\
12,100\end{array}$ & $\begin{array}{r}120 \\
40 \\
* 3,740\end{array}$ \\
\hline $\begin{array}{l}09 \\
12 \\
14\end{array}$ & $\begin{array}{r}700 \\
370 \\
2,220\end{array}$ & $\begin{array}{r}120 \\
50 \\
* \quad 260\end{array}$ \\
\hline $\begin{array}{l}15 \\
16 \\
19\end{array}$ & $\begin{array}{l}1,650 \\
2,350 \\
1,100\end{array}$ & $\begin{array}{r}110 \\
* \quad 350 \\
130\end{array}$ \\
\hline $\begin{array}{l}20 \\
22 \\
29\end{array}$ & $\begin{array}{r}520 \\
3,490 \\
1,970\end{array}$ & $\begin{array}{r}40 \\
* \quad 670 \\
* \quad 250\end{array}$ \\
\hline $\begin{array}{l}34 \\
36 \\
37\end{array}$ & $\begin{array}{r}3,200 \\
1,160 \\
800\end{array}$ & $\begin{array}{r}640 \\
70 \\
50\end{array}$ \\
\hline $\begin{array}{l}39 \\
42 \\
43\end{array}$ & $\begin{array}{r}2,150 \\
810 \\
830\end{array}$ & $\begin{array}{r}240 \\
30 \\
50\end{array}$ \\
\hline $\begin{array}{l}45 \\
46 \\
47\end{array}$ & $\begin{array}{r}800 \\
2,100 \\
2,350\end{array}$ & $\begin{array}{r}50 \\
* \quad 310 \\
* \quad 440\end{array}$ \\
\hline $\begin{array}{l}48 \\
51 \\
53\end{array}$ & $\begin{array}{r}2,330 \\
1,180 \\
920\end{array}$ & $\begin{array}{r}* 425 \\
50 \\
20\end{array}$ \\
\hline $\begin{array}{l}54 \\
55 \\
56\end{array}$ & $\begin{array}{r}940 \\
1,120 \\
2,030\end{array}$ & $\begin{array}{r}30 \\
-- \\
180\end{array}$ \\
\hline
\end{tabular}


Table 6.--Specific conductance and chloride concentrations in ground water at selected wells in Lajas Valley, March 1986--Continued

[units $-\mu \mathrm{S} / \mathrm{cm}$, microsiemens per centimeter at 25 degrees Celsius;

$\mathrm{mg} / \mathrm{L}$, milligrams per liter; ---, indicates data not available;

* indicates sample exceeds 1973 U.S. Environmental Protection

Agency drinking water standard of 250 milligrams per liter for chloride; Source: U.S. Environmental Protection Agency, 1973]

\begin{tabular}{|c|c|c|}
\hline $\begin{array}{c}\text { Well } \\
\text { number } \\
\text { (appendix) }\end{array}$ & $\begin{array}{l}\text { Specific conductance } \\
(\mu \mathrm{S} / \mathrm{cm})\end{array}$ & $\begin{array}{l}\text { Chloride concentration } \\
(\mathrm{mg} / \mathrm{L})\end{array}$ \\
\hline $\begin{array}{l}58 \\
60 \\
62\end{array}$ & $\begin{array}{l}1,020 \\
5,300 \\
1,020\end{array}$ & $\begin{array}{r}80 \\
* \quad 1,460 \\
. \quad 50\end{array}$ \\
\hline $\begin{array}{l}63 \\
64 \\
65\end{array}$ & $\begin{array}{l}1,820 \\
2,280 \\
2,050\end{array}$ & $\begin{array}{r}220 \\
* \quad 340 \\
* \quad 355\end{array}$ \\
\hline $\begin{array}{l}66 \\
68 \\
69\end{array}$ & $\begin{array}{l}1,480 \\
2,600 \\
2,710\end{array}$ & $\begin{array}{r}160 \\
* \quad 480\end{array}$ \\
\hline $\begin{array}{l}70 \\
72 \\
73\end{array}$ & $\begin{array}{r}1,790 \\
1,150 \\
800\end{array}$ & $\begin{array}{r}240 \\
100 \\
45\end{array}$ \\
\hline $\begin{array}{l}75 \\
76 \\
78\end{array}$ & $\begin{array}{r}82 \\
1,380 \\
1,230\end{array}$ & $\begin{array}{r}45 \\
140 \\
75\end{array}$ \\
\hline $\begin{array}{l}84 \\
85 \\
86\end{array}$ & $\begin{array}{r}1,550 \\
2,920 \\
421\end{array}$ & $\begin{array}{r}175 \\
* \quad 445 \\
60\end{array}$ \\
\hline $\begin{array}{l}87 \\
88 \\
90\end{array}$ & $\begin{array}{r}850 \\
1,120 \\
1,430\end{array}$ & $\begin{array}{r}60 \\
60 \\
175\end{array}$ \\
\hline $\begin{array}{l}94 \\
96 \\
97\end{array}$ & $\begin{array}{l}2,580 \\
5,200 \\
1,290\end{array}$ & $\begin{array}{r}240 \\
* \quad 1,600 \\
100\end{array}$ \\
\hline $\begin{array}{r}99 \\
103 \\
109\end{array}$ & $\begin{array}{r}750 \\
1,200 \\
820\end{array}$ & $\begin{array}{r}--- \\
90 \\
130\end{array}$ \\
\hline $\begin{array}{l}110 \\
111 \\
117\end{array}$ & $\begin{array}{r}439 \\
1,500 \\
1,010\end{array}$ & $\begin{array}{r}50 \\
* \quad 325 \\
55\end{array}$ \\
\hline
\end{tabular}


Table 6.--Specific conductance and chloride concentrations in ground water at selected wells in Lajas Valley, March 1986--Continued

[units $-\mu \mathrm{S} / \mathrm{cm}$, microsiemens per centimeter at 25 degrees Celsius;

$\mathrm{mg} / \mathrm{L}$, milligrams per liter; ---, indicates data not available;

* indicates sample exceeds 1973 U.S. Environmental Protection

Agency drinking water standard of 250 milligrams per liter for chloride; Source: U.S. Environmental Protection Agency, 1973]

\begin{tabular}{ccc}
\hline $\begin{array}{c}\text { Well } \\
\text { number } \\
\text { (appendix) }\end{array}$ & $\begin{array}{c}\text { Specific conductance } \\
(\mu S / \mathrm{cm})\end{array}$ & $\begin{array}{c}\text { Chloride concentration } \\
(\mathrm{mg} / \mathrm{L})\end{array}$ \\
\hline 119 & 1,230 & 60 \\
120 & 1,600 & 220 \\
122 & 1,120 & 100 \\
124 & 1,350 & 100 \\
125 & 1,360 & 100 \\
126 & 1,010 & 80 \\
127 & 1,230 & 100 \\
132 & 200 & 15 \\
133 & 2,500 & 190 \\
& & $* 410$ \\
134 & & $* 2,980$ \\
138 & 2,550 & $* 6,760$ \\
139 & 9,200 & $* 260$ \\
149 & 17,100 & $* 5,700$ \\
155 & & $* 1,280$ \\
156 & 2,646 & \\
& 16,200 &
\end{tabular}


the alluvial fan deposits. If deeper test wells were drilled at well battery A, elevated chloride concentrations, such as those measured at well batteries B and C, might be encountered.

During March 1986, water samples were collected from all available wells located in the Lajas Valley in order to map chloride concentrations (table 6). The wide variation in chloride concentration with depth, in combination with the number of wells that have different screen intervals with respect to land surface datum, necessitated the construction of three separate chloride concentration maps. Wells used to prepare these maps were divided into the following categories according to depth; 39 feet or less, 40 to 79 feet, and greater than 79 feet (fig. 15, 16, and 17). This permitted a more accurate method of describing chloride concentrations in the valley.

Chloride concentrations generally were less than $200 \mathrm{mg} / \mathrm{L}$ in wells along the northern edge and locally along the southern edge of the alluvial valley (fig. 15, 16, and 17). The relatively low chloride concentrations in these areas can be attributed to ground-water recharge from the more permeable alluvial fans. Wells in the center of the valley were found to have chloride concentrations as high as $6,700 \mathrm{mg} / \mathrm{L}$. The highest chloride concentrations were generally in water from wells deeper than 79 feet. Wells drilled to depths of 40 to 79 feet generally had the lowest chloride concentrations. This pattern is similar to the patterns observed at well batteries $\mathrm{B}$ and $\mathrm{C}$ and is attributed to the effect of evapotranspiration at shallow depths and connate water at greater depths.

\section{SUMMARY}

The principal aquifer in the Lajas Valley is a confined aquifer consisting of alluvial deposits of Quaternary age. The altitude of the potentiometric surface of the Lajas Valley alluvial aquifer ranges from more than 50 feet above mean sea level along the northern and southern boundaries of the valley to about 12 feet above mean sea level in the central part of the valley. Values of aquifer transmissivity range from 670 to 8,020 square feet per day; and the storage coefficient of the aquifer is approximately 0.00093 .

Water-quality analyses of ground water in the alluvial aquifer indicated that, at several sites, the drinking water standards for iron, manganese, chloride, and total dissolved solids established by the U.S. Environmental Protection Agency were exceeded. Elevated chloride concentrations in excess of $5,000 \mathrm{mg} / \mathrm{L}$ were measured in water samples from several wells.

Consolidated clastic and carbonate strata of Cretaceous and Tertiary age underlie the alluvial aquifer. Chloride concentrations in ground water in wells screened in this rock ranged from 100 to $2,100 \mathrm{mg} / \mathrm{L}$. 


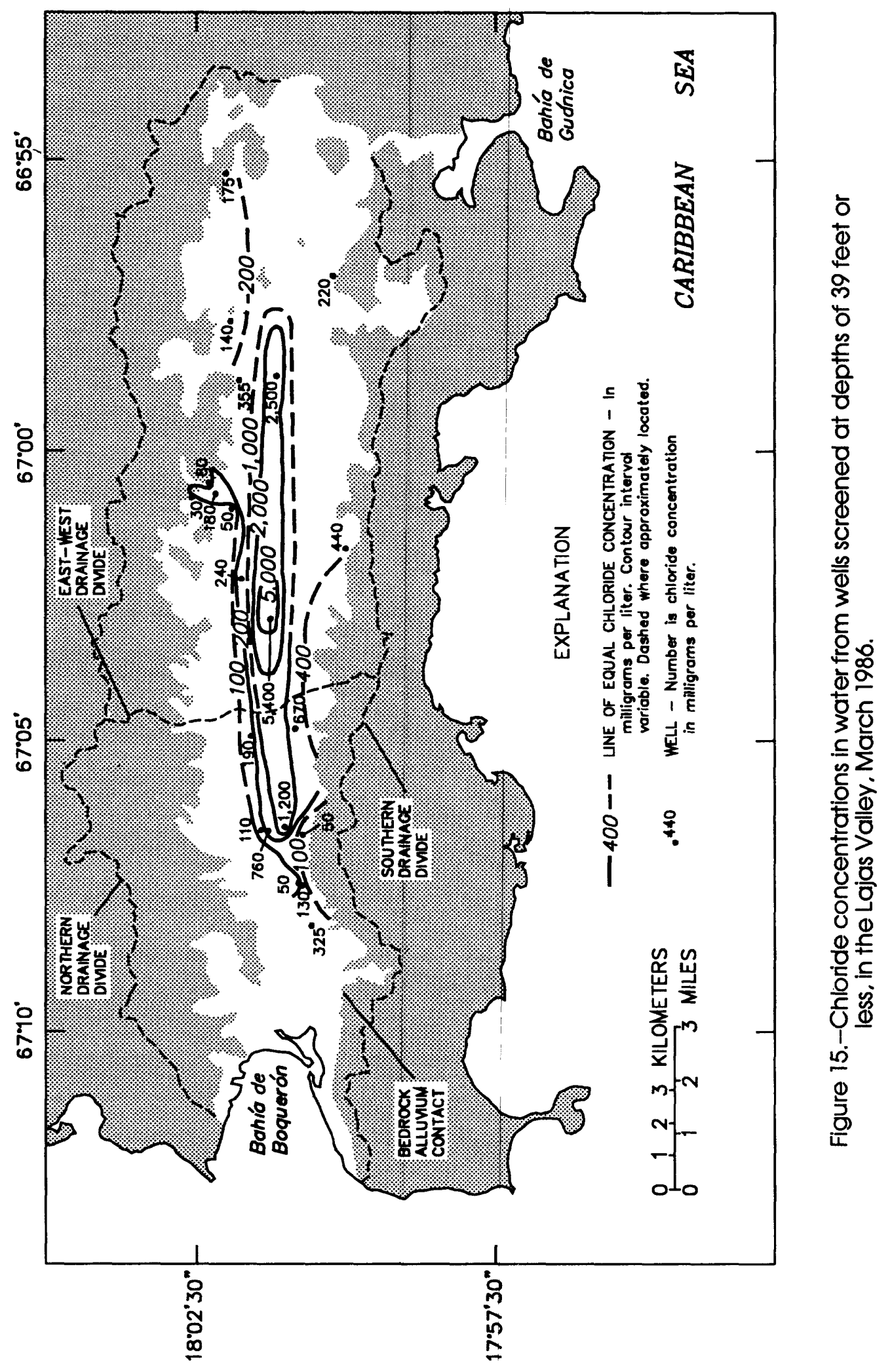




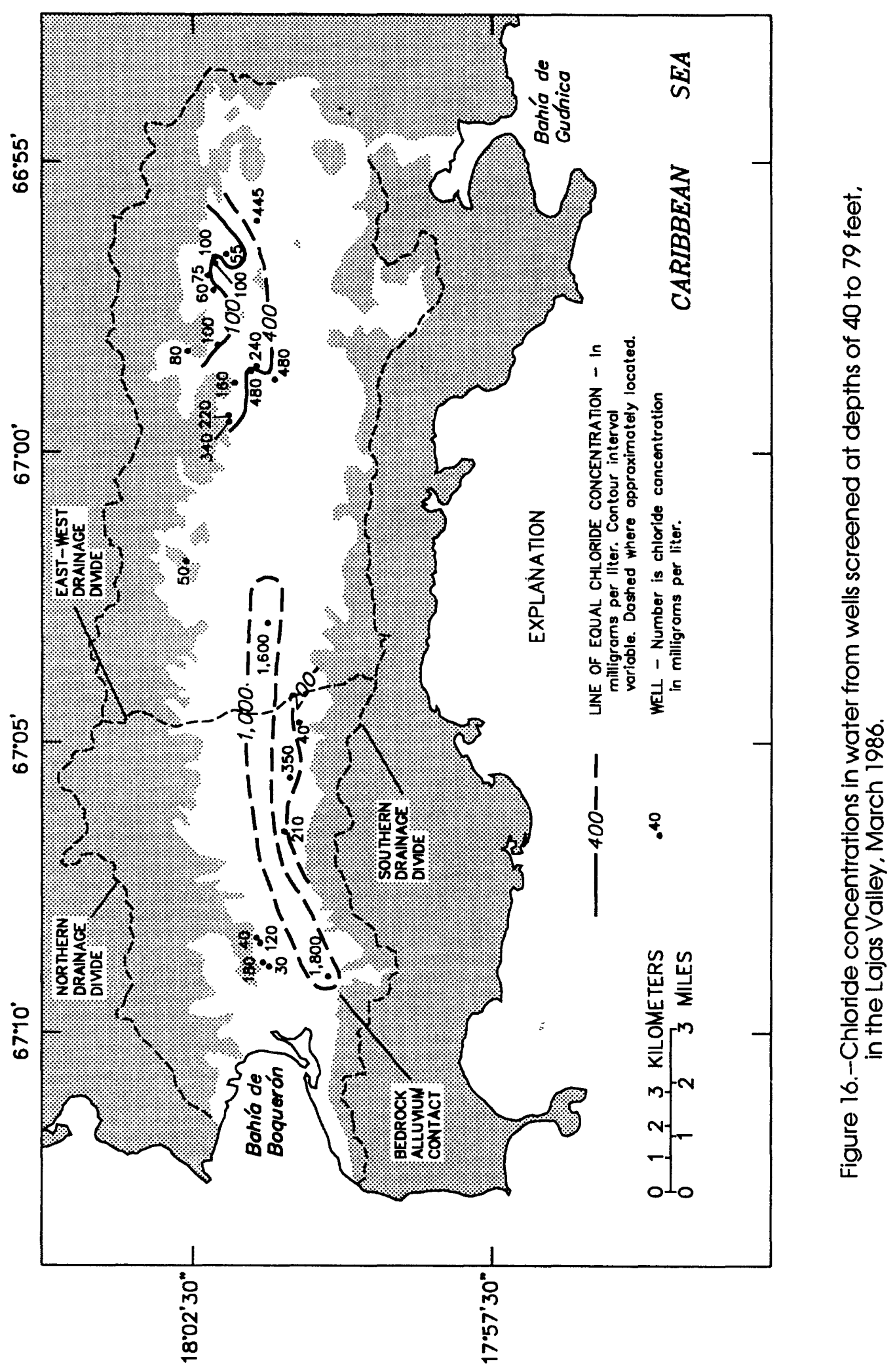




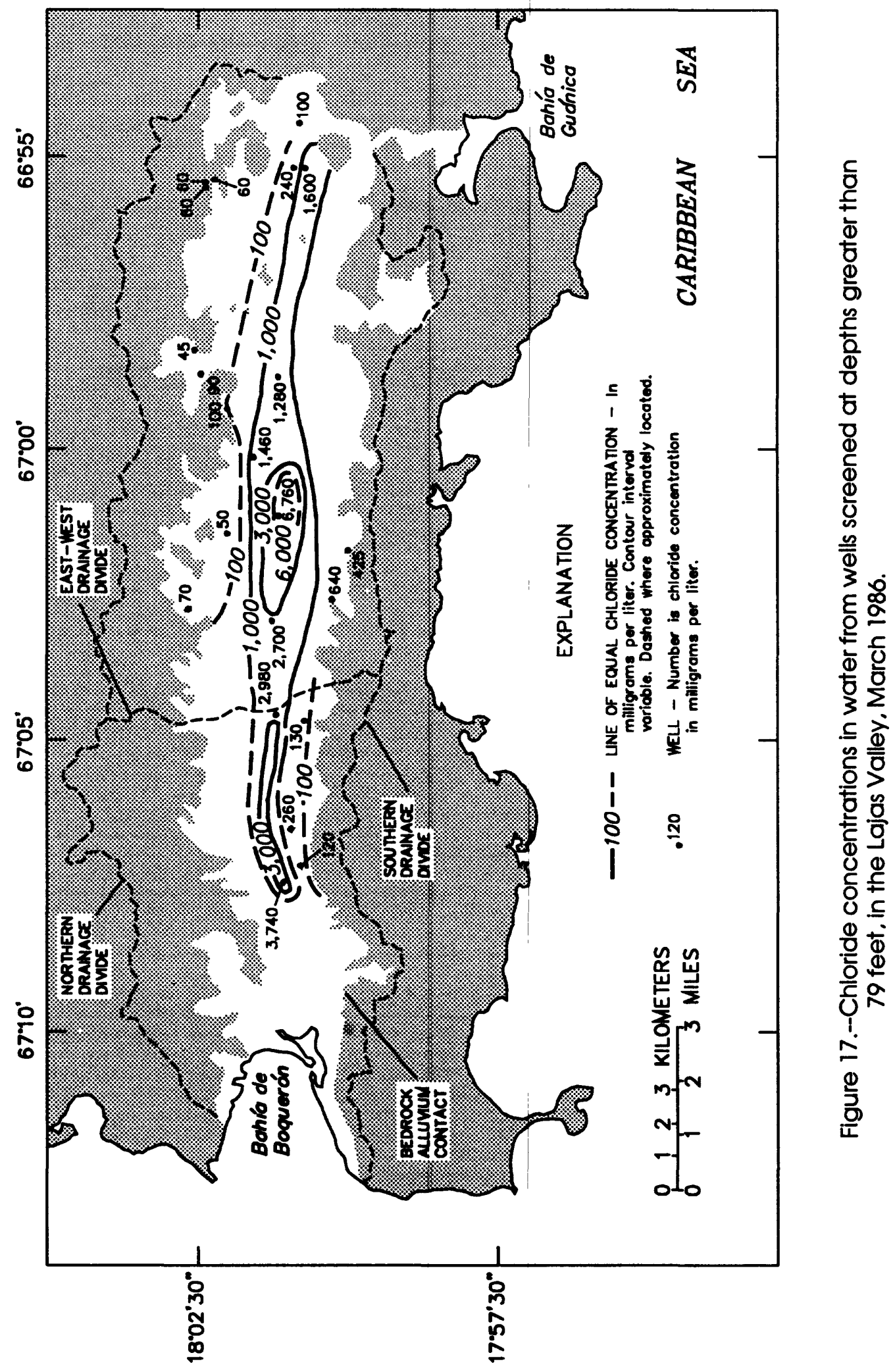




\section{REFERENCES}

Anderson, H.R., 1977, Ground water in the Lajas Valley: U.S. Geological Survey Water-Resources Investigations Report 68-76, $45 \mathrm{p}$.

Bonnet, J.A., and Brenes, E.J., 1958, Detailed salinity survey of Lajas Valley: University of Puerto Rico, Agricultural Experiment Station, Río Piedras, Puerto Rico, Bulletin 141, 114 p.

Jones, C.F., and Pico, Rafael, 1955, Symposium on the geography of Puerto Rico: University of Puerto Rico Press, 503 p.

Lohman, S.W., 1979, Ground-water hydraulics: U.S. Geological Survey Professional Paper 708, $70 \mathrm{p}$.

Lugo-López, M.A., Pérez-Escolar, R., Acevedo, G., and Juarez Jr., J., 1959, Nature and properties of major soils of Lajas Valley: University of Puerto Rico, Agricultural Experimental Station, Río Piedras, Puerto Rico, Bulletin 149, 60 p.

Meyer, R.R., 1963, A chart relating well diameter, specific capacity, and the coefficient of transmissibility and storage, in Bentall, Ray, compiler, Methods of determining permeability, transmissibility, and drawdown: U.S. Geological Survey Water-Supply Paper 1536-I, p. 338-340.

McGuinness, C.L., 1948, Ground-water resources of Puerto Rico: U.S. Geological Survey Open-File Report, 613 p.

U.S. Environmental Protection Agency Drinking Standards, 1973, Water quality criteria, 1972 - A report of the committee on.water quality criteria: National Academy of Sciences, National Academy of Engineering, Washington, D.C., EPA. R3.73.033, 594 p.

1986, Quality criteria for water 1986, EPA 440/5-86-001, Office of Water Regulations and Standards, Washington D.C.

U.S. Department of Commerce, 1986, Climatological data annual summary- Puerto Rico and Virgin Islands: National Oceanic and Atmospheric Administration, Volume 32, Number 13, $23 \mathrm{p}$.

Vázquez, Roberto, and Vélez, J.O. 1967, Drainage and ground-water research in Lajas Valley, Puerto Rico: University of Puerto Rico, Mayagüez Campus, Agricultural Experimental Station, Bulletin 206, 37 p.

Volckmann, R.P., 1984a, Geologic map of the Cabo Rojo and Parguera quadrangles, southwest Puerto Rico: U.S. Geological Survey Miscellaneous Investigations Series Map I-1557.

1984b, Geologic map of the Puerto Real quadrangle, southwest Puerto Rico: U.S. Geological Survey Miscellaneous Investigations Series Map I-1559.

$1984 c$ Geologic map of the San Germán quadrangle, southwest Puerto Rico: U.S. Geological Survey Miscellaneous Investigations Series Map I-1558.

1984d, Upper Cretaceous stratigraphy of southwest Puerto Rico: U.S. Geological Survey Bulletin 1537-A, p. A73-A83. 












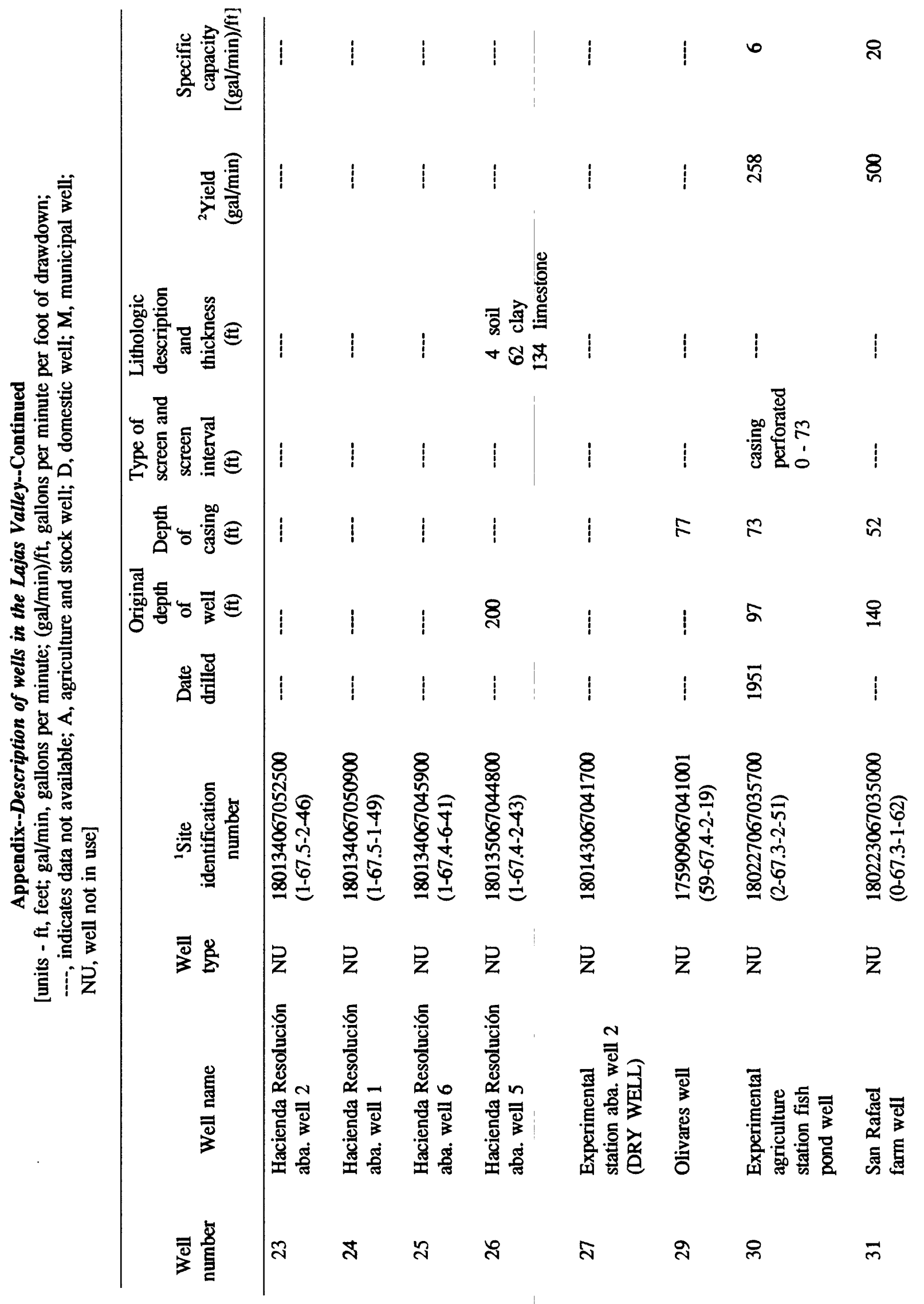




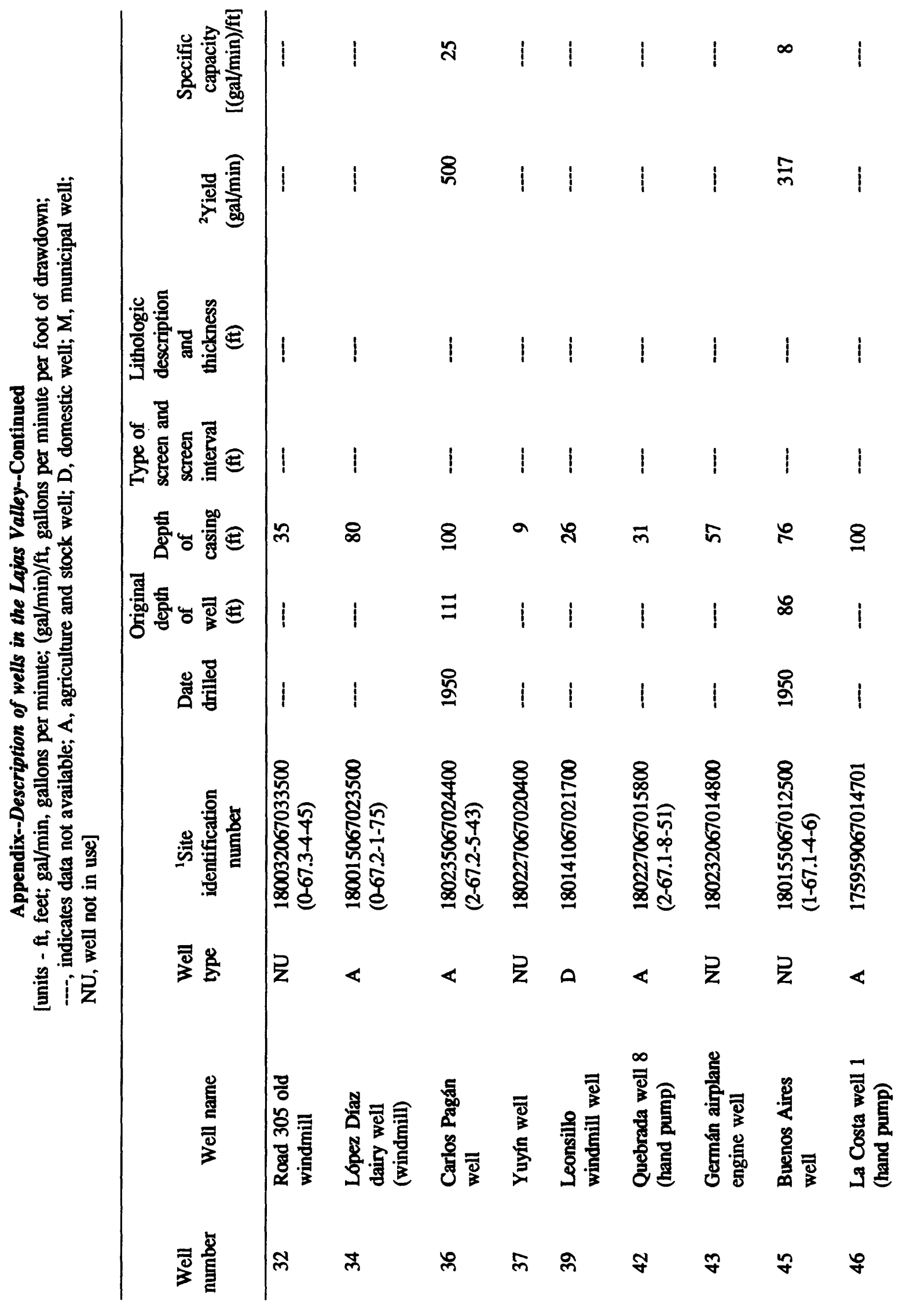




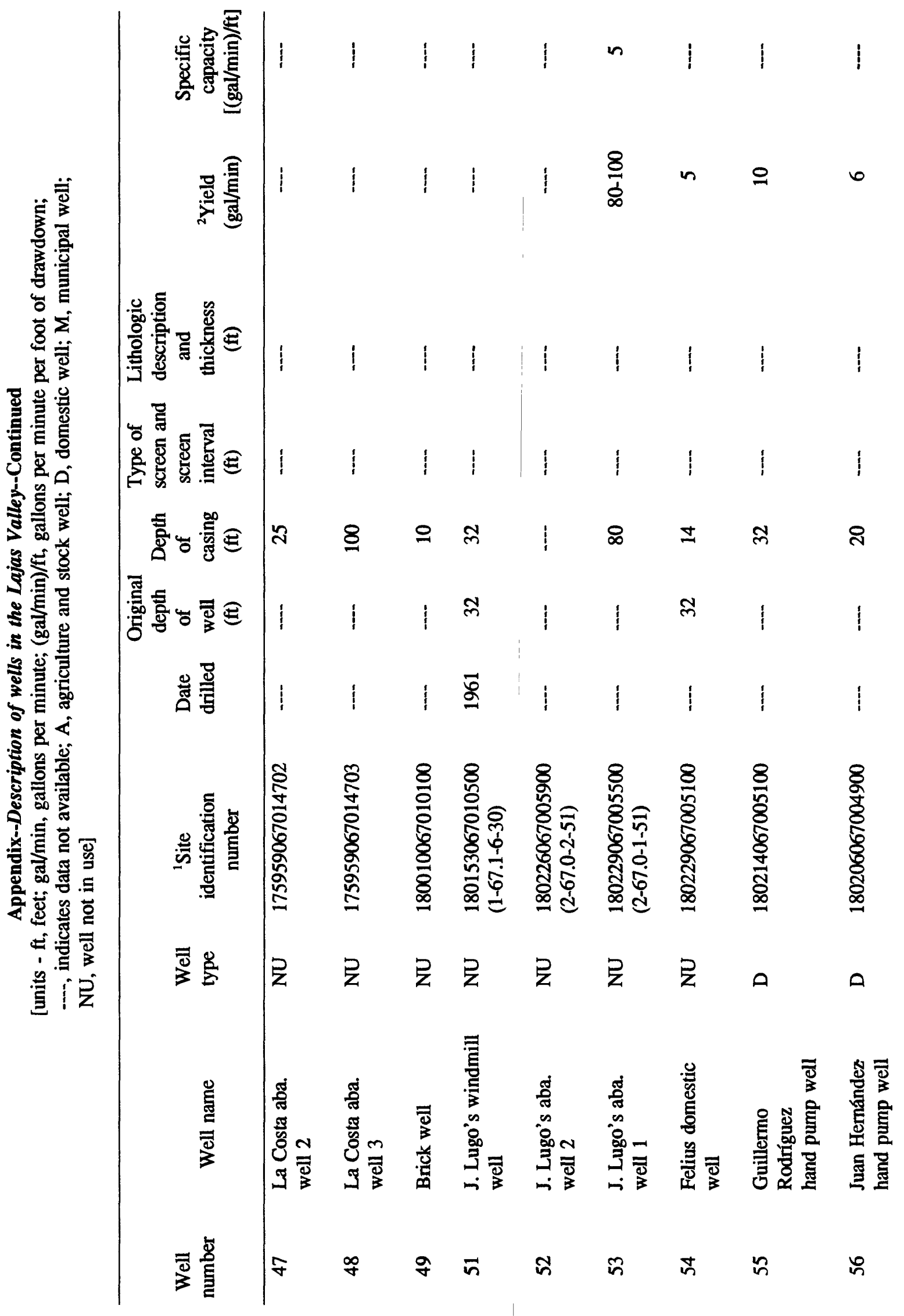









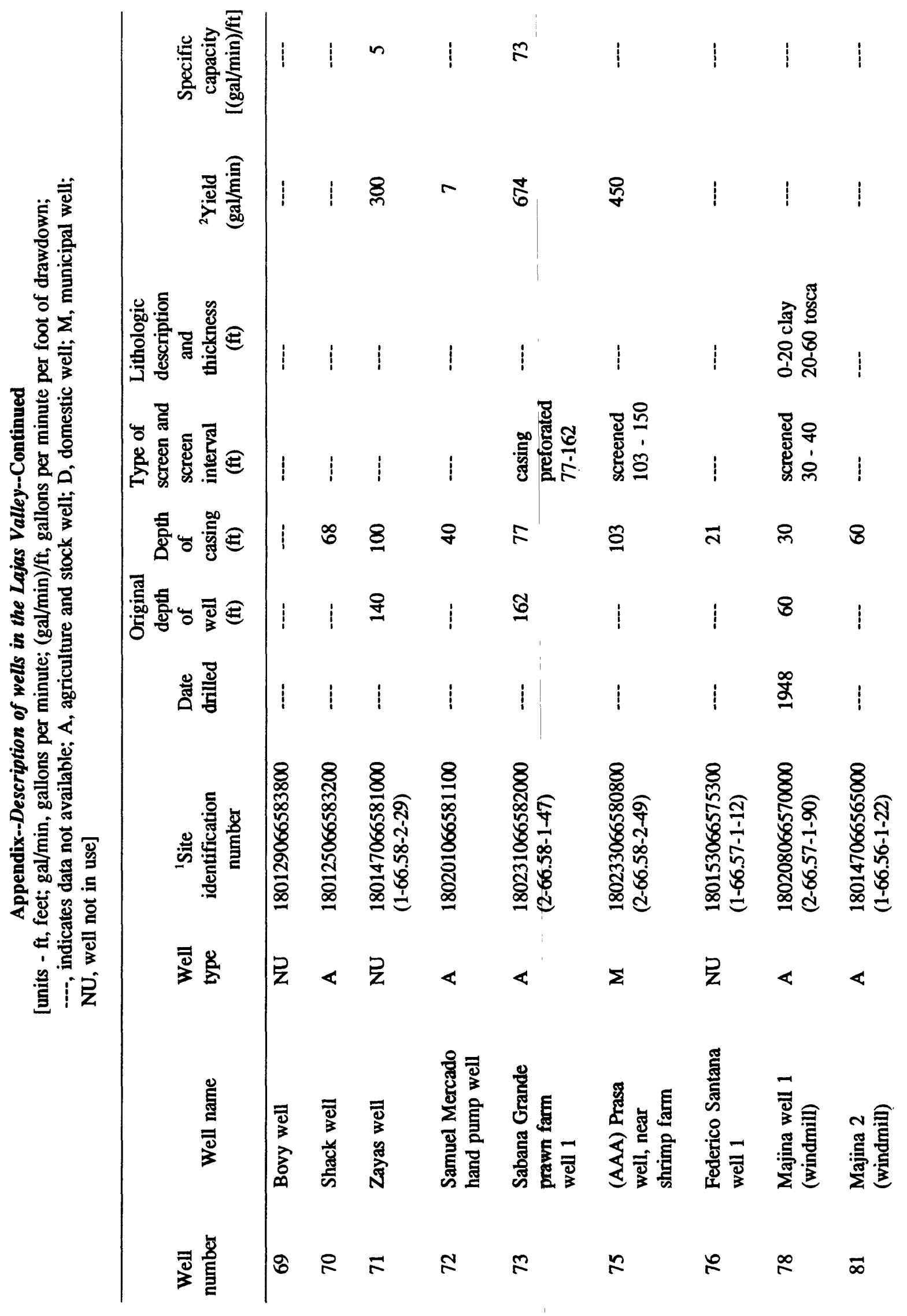




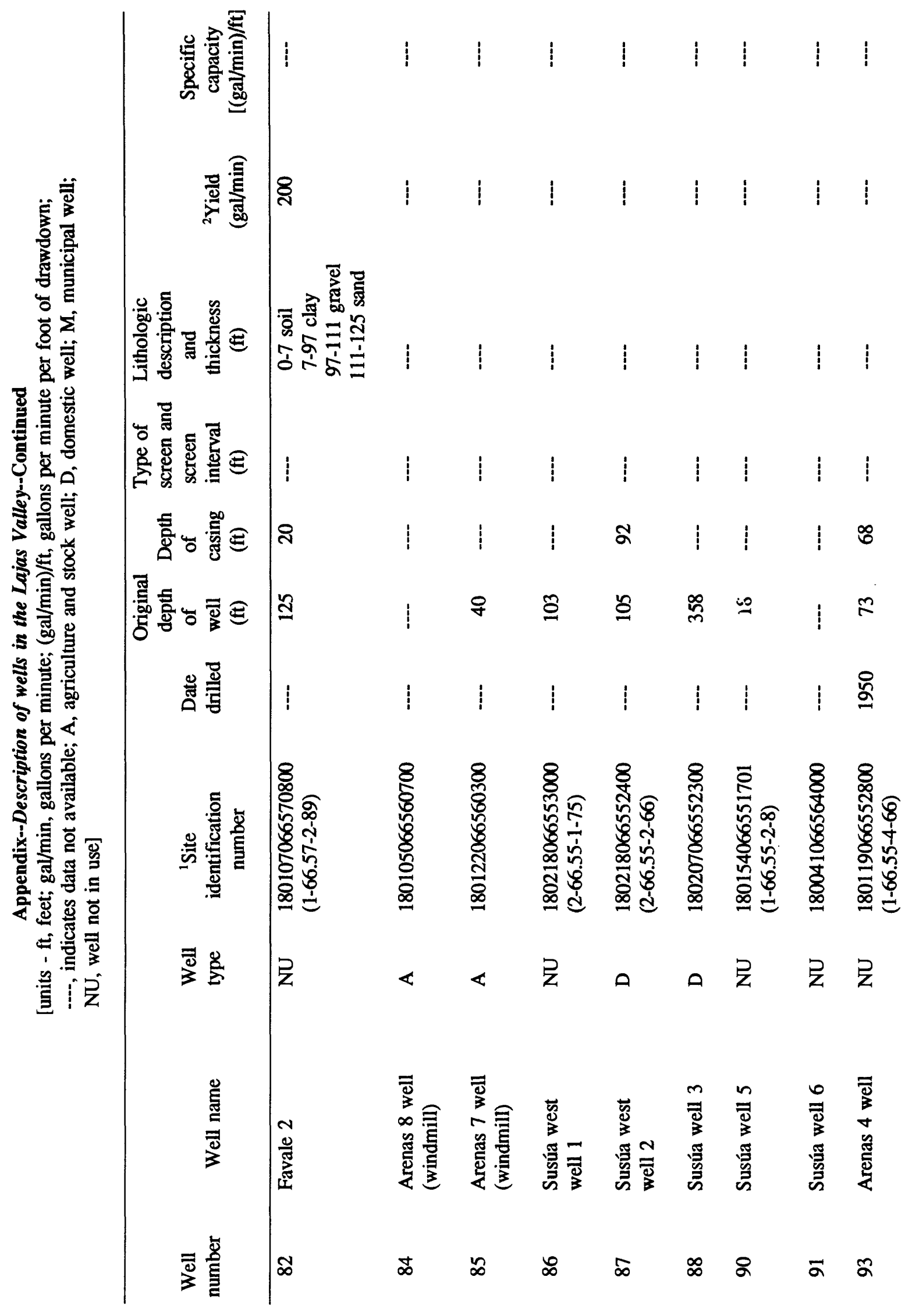




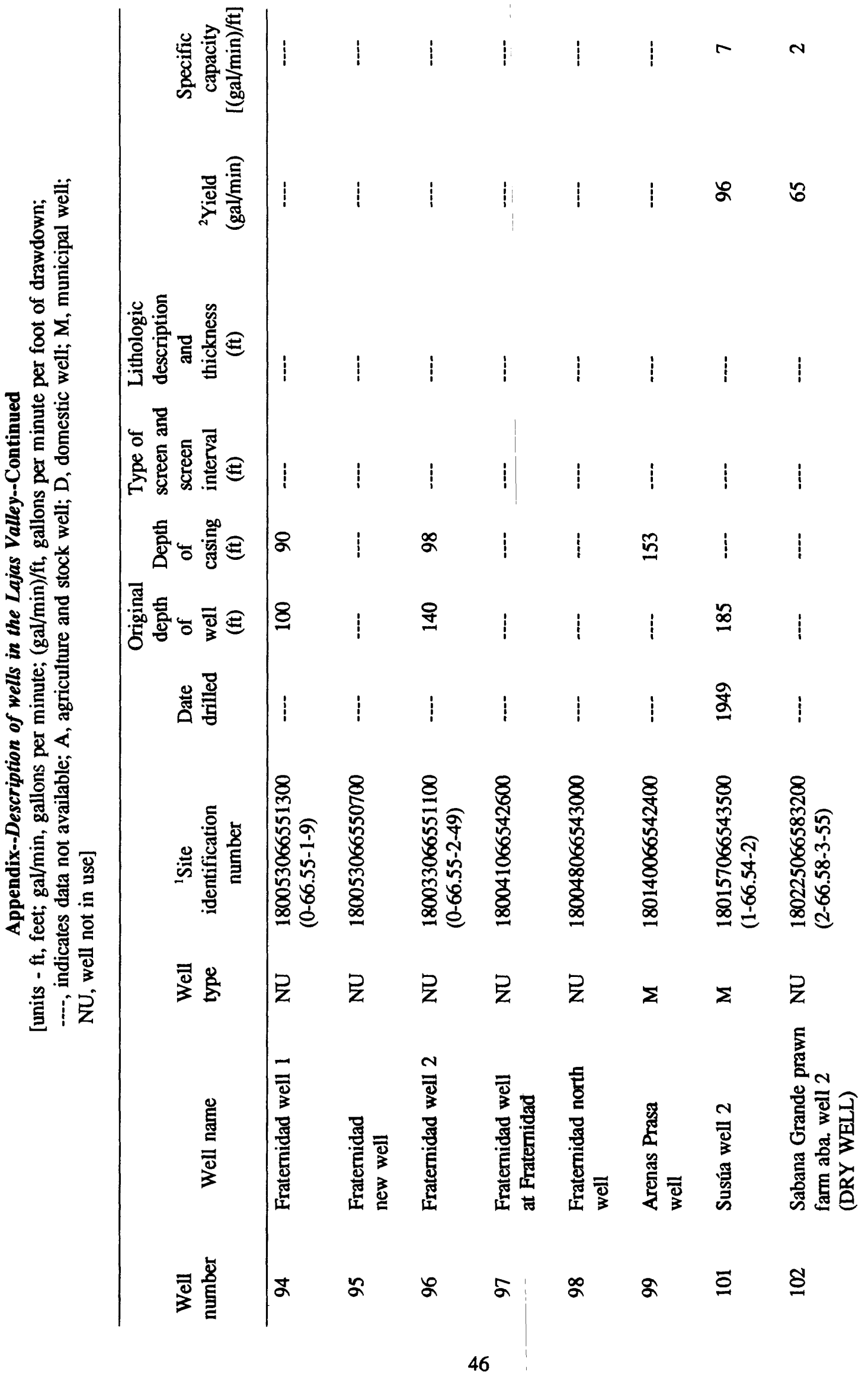
























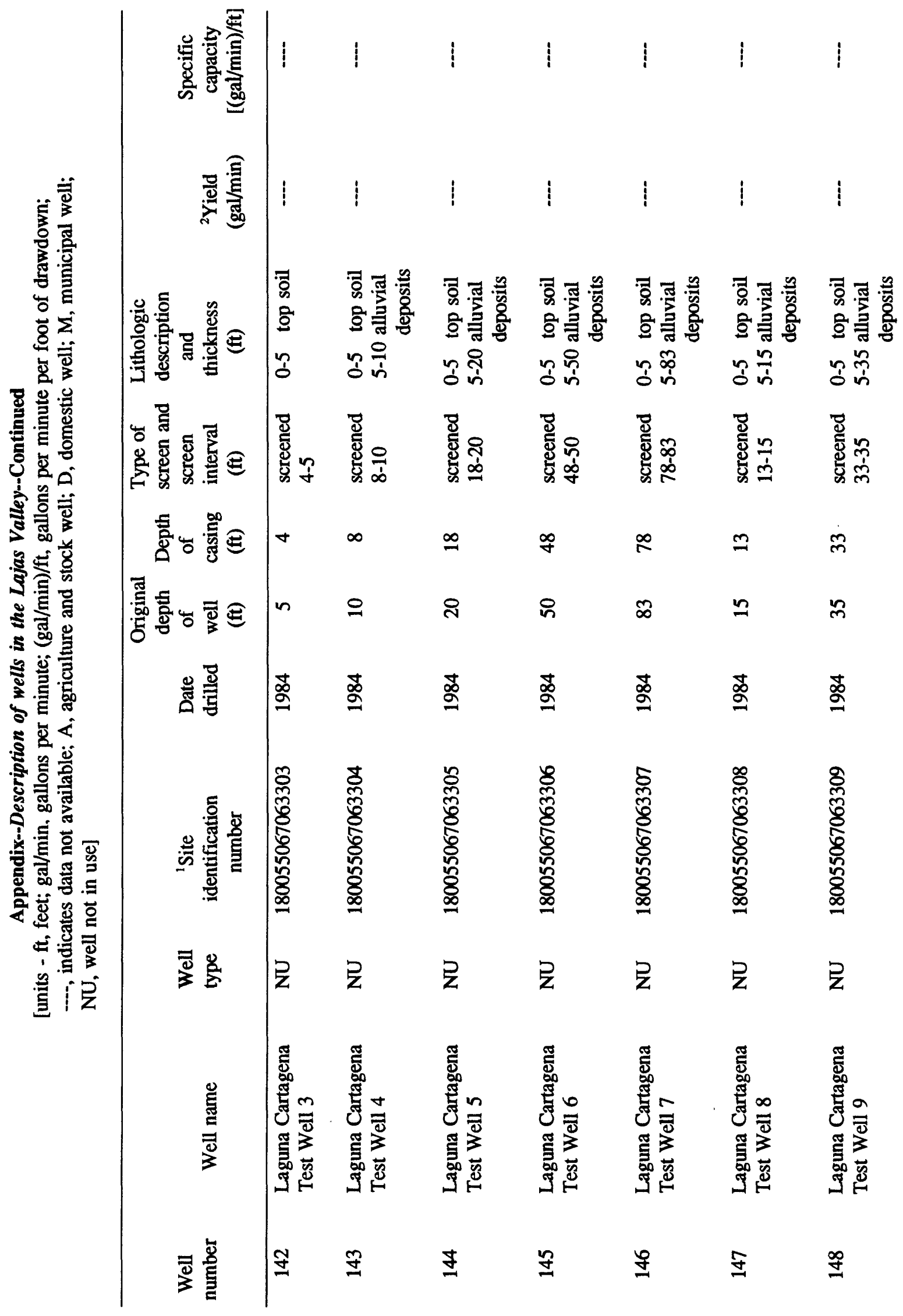




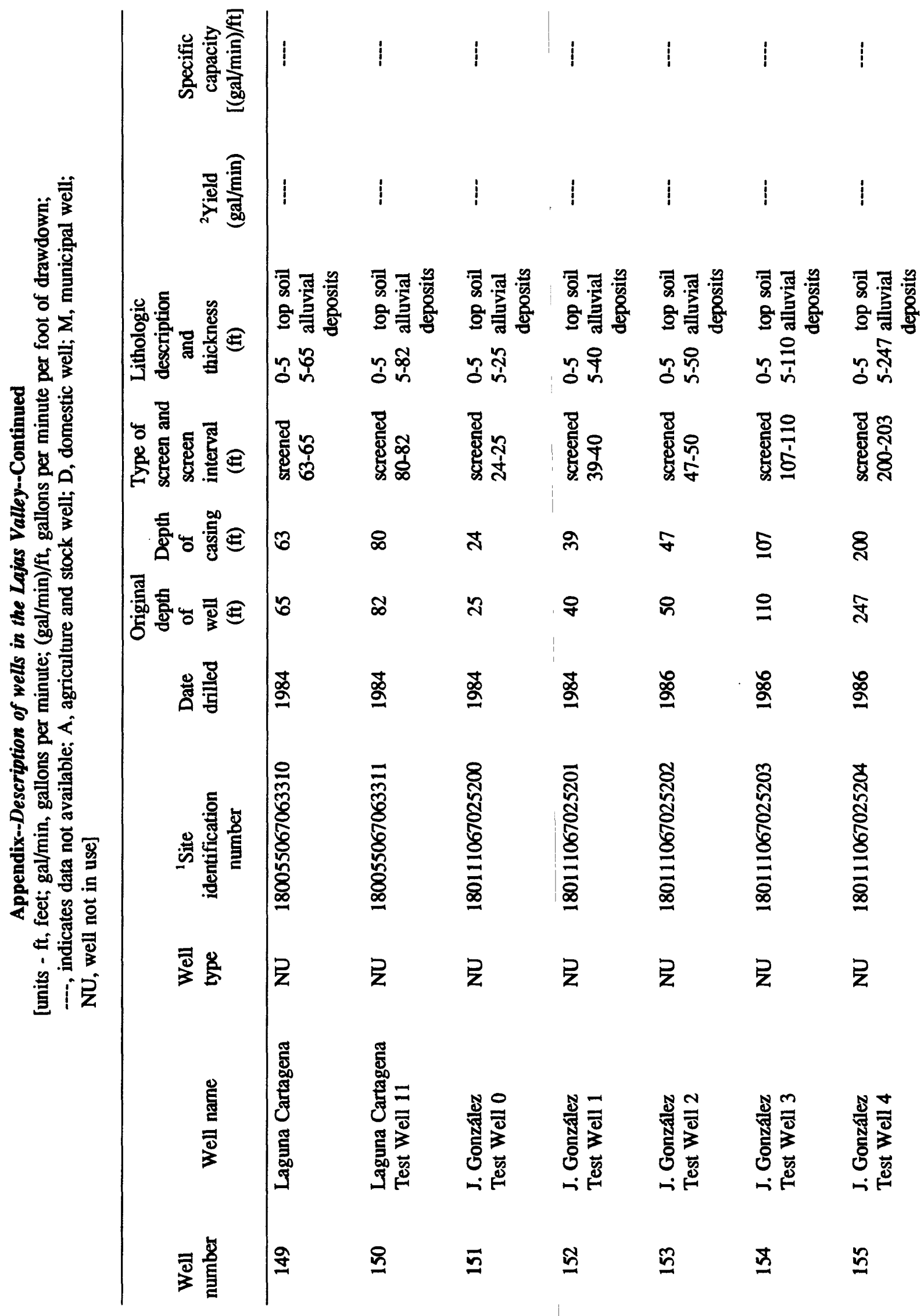









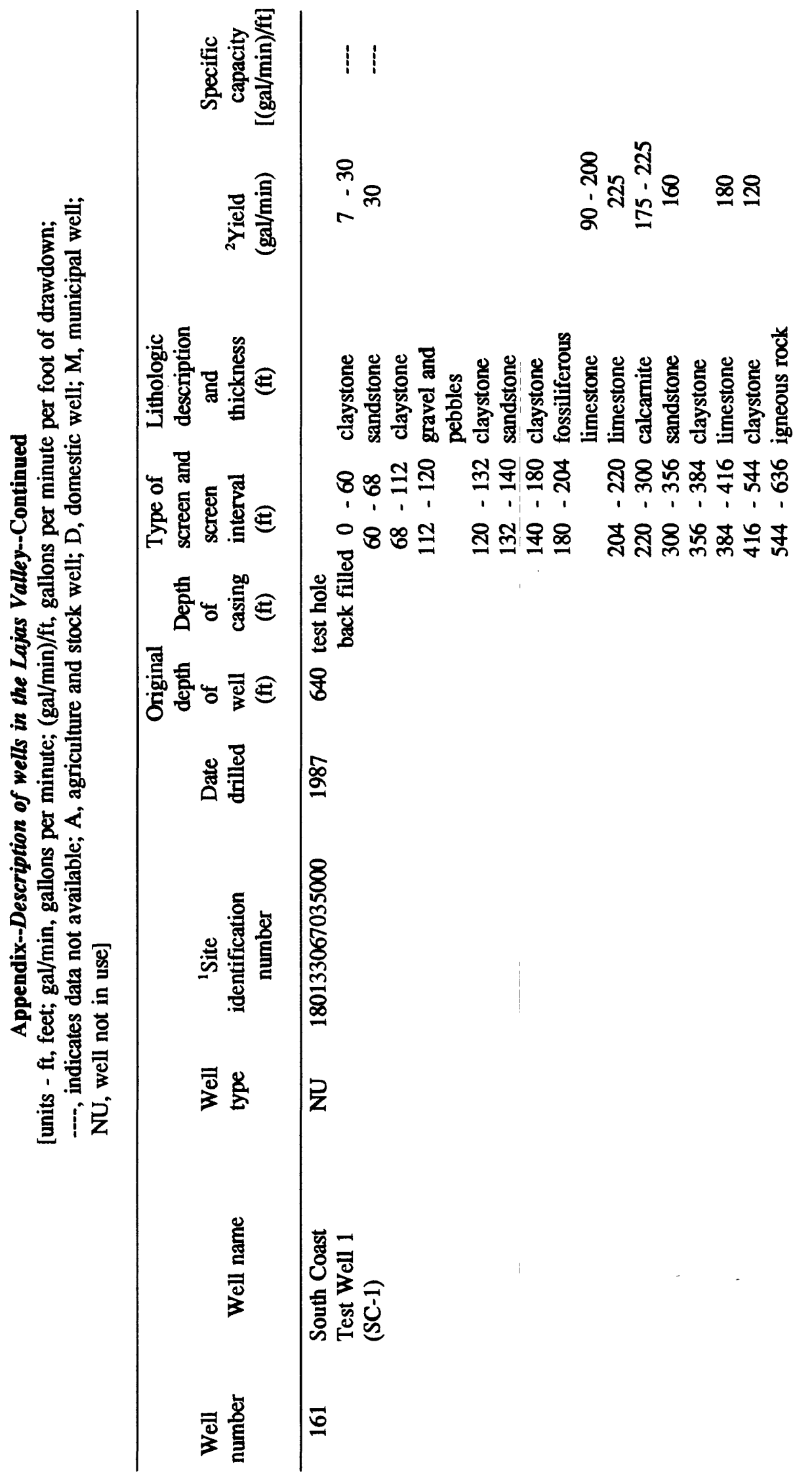




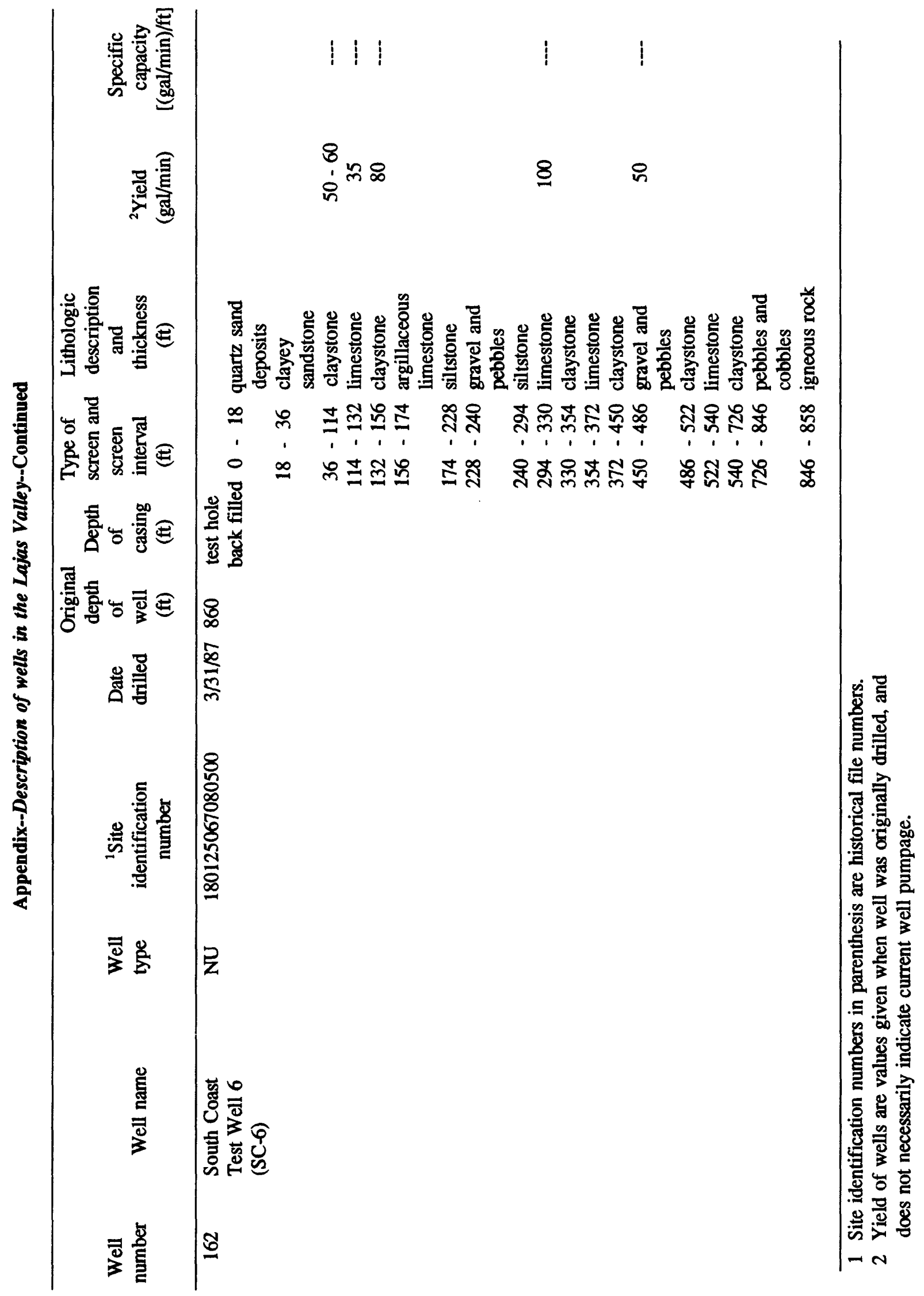

